\title{
Examining How Biology Teachers' Pedagogical Beliefs Shape the Implementation of the Omani Reform-Oriented Curriculum
}

\author{
By Intisar Ambusaidi ${ }^{*}$, Bernard Badiali ${ }^{\dagger} \&$ \\ Khalid Alkharousi
}

\begin{abstract}
Research on science-education reform affirms the importance of taking into consideration teachers' pedagogical beliefs in relation of the constructivist perspective to ensure successful implementation of a reform-oriented curriculum. In addition, prominent studies pinpoint the need for teachers to have sufficient pedagogical content knowledge (PCK) to adapt a reform-oriented science curriculum to meet students' abilities and interests. This study focused on the reform-oriented science curriculum in Oman, and in particular, the grade 12 biology curriculum. The new biology curriculum emphasizes constructivism and encourages student-centered instruction, inquiry-based learning, cooperative learning, problem-solving, and critical thinking. However, since its implementation in 2008, various obstacles and challenges have been reported by teachers. These include a mismatch between the planned curriculum and the implemented curriculum. This mismatch has been attributed to a lack of motivation and PCK among teachers that would allow them to shift their teaching practices. Consequently, the purpose of this study was to understand how teachers' pedagogical beliefs about student-centered learning have shaped their implementation of the curriculum. The study also sought to identify how biology teachers perceive the relationship between their PCK and their pedagogical decisions. An ethnographic approach to data analysis was employed, with multiple data sources including classroom observations, learning artifacts, reflections, and semi-structured interviews used. The findings of this ethnographic study indicate that Omani teachers' beliefs and PCK shape the implementation of the reform-oriented curriculum by influencing their conceptualization of the curriculum, their identification of students' misconceptions, their decisions about classroom teaching practices, and the level of their students' engagement. The results of this study corroborate and expand upon previous research that suggests that teachers' beliefs and PCK should be taken into consideration when designing and planning for new curriculum materials, teacher-education programs, and professional development opportunities.
\end{abstract}

Keywords: pedagogical beliefs, reform-oriented curriculum, pedagogical content knowledge (PCK), constructivism, curriculum implementation.

\section{Introduction}

Teachers are considered the most effective and important agents in improving students' motivation and science learning. Teachers' beliefs about science, pedagogy, and students' understanding influence their classroom actions, functioning as filters through which the teachers make their decisions.

\footnotetext{
*PhD Candidate \& Graduate Assistant, The Pennsylvania State University, USA.

${ }^{\dagger}$ Associate Professor, The Pennsylvania State University, USA.

${ }^{\star}$ Biology Senior Supervisor, Ministry of Education, Oman.
} 
Understanding teachers' beliefs and how they inform their instruction is critical to improve science education. The recent global reform of science education, which is rooted in constructivism, has introduced assumptions about learning and approaches to teaching that are together known as reform-oriented instruction (Le, Lockwood, Stecher, Hamilton, \& Matinz, 2009). Reform-oriented instruction is marked by three key characteristics: It is (a) standards-based, (b) student-centered, and (c) inquiry-oriented (Sawada et al., 2002).

Reform-oriented instruction implies that teachers seek to understand the processes and levels at which students comprehend scientific concepts and then adjust the design of instruction in such a way as to challenge students' perceptions (Park, Jang, Chen, \& Jung, 2011). Therefore, teachers need to develop particular types of knowledge that enable them to transform the content knowledge (CK) they have into pedagogically powerful forms but that also give them the flexibility to adapt to their students' differences in prior knowledge, interests, understanding levels, and learning preferences (Park et al., 2011). This knowledge is what Shulman $(1986,1987)$ conceptualized as pedagogical content knowledge (PCK). Some scholars (e.g., Park et al., 2011) have assumed that PCK is essential for teachers' successful implementation of instructional practices that are aligned with the underlying principles of reform-oriented science education.

Given the ongoing global reform movement in science education, it is essential to analyze to what extent teachers implement reform-oriented teaching practices (RTPs) in their classrooms. Understanding teachers' beliefs about teaching and their perceptions of reform is critical because beliefs and perceptions impact teachers' motivation to change their instructional practices and to achieve the reform goals.

\section{Background}

Oman engaged in a major educational reform in 1998 and introduced a Basic Education System (BES, grades 1-10) with the aim of enhancing students' learning outcomes (Al-Balushi \& Griffiths, 2013). BES emphasizes a studentcentered approach to learning, inquiry-based learning, and continuous assessment (Ministry of Education [MOE], Oman \& World Bank, 2012). In 2008, a new PostBasic Education System (Post-BES, grades 11 and 12) was introduced. Almost two decades after the implementation of the reform-oriented curriculum, there is evidence from a variety of sources to suggest that students' learning outcomes lag behind expectations at the national and international levels (MOE \& World Bank, 2012). Additionally, new teachers' skills have not been adequately developed through pre-service teacher education due to a lack of emphasis on pedagogical skills and the limited use of practical training (Issan \& Gomaa, 2010).

We believe that the mismatch between the planned curriculum and the implemented curriculum stems from a top-down approach to policymaking and curriculum development. In particular, we argue that the new curriculum introduced student-centered and inquiry-based instructional approaches without properly preparing teachers and ensuring the adequacy of the learning 
environment. Teachers often shape and alter a new curriculum if they find that it is inconsistent with their beliefs (Pedersen \& Liu, 2003). Therefore, the effective design of a student-centered curriculum must take into account teachers' beliefs about student-centered learning and the likely influence of these beliefs on teachers' implementation of the curriculum (Richardson, 1990; Pajares, 1992).

\section{Research Questions}

This study addresses the following primary research question: How have biology teachers' pedagogical beliefs shaped the implementation of the reformoriented curriculum in Muscat, Oman? The secondary research questions are:

1. What types of biology curriculum implementation and practices are twelfth graders actually encountering, as observed in biology classrooms?

2. How do biology teachers rationalize their practices and curriculum implementtation decisions in light of their personal beliefs regarding the reformed biology curriculum?

3. How do biology teachers' perceptions of the relationships between PCK and reform-oriented practices influence their approaches to teaching the curriculum in their classrooms?

\section{Literature Review}

\section{Theoretical Framework: Constructivism and Socio-Constructivism}

Constructivism was used as the framework for this study because it is considered the philosophical and theoretical rationale underlying the current reform movement. Constructivism theorizes that knowledge is not discovered but constructed by individuals based on experiences that are developmentally, socially, and culturally mediated (Fosnot, 1996). Vygotsky's theory (1986) indicates not only that all learning is socially mediated, but also that it is affected by a child's present and past experiences as an active member of society. Learning science from a constructivist perspective is thus an active, social process of making sense of experiences and is something students do, not something that is done to them (National Research Council [NRC], 1996).

From the socio-constructivist perspective, the role of the learner is one of selecting and transforming information, constructing knowledge, and making decisions, rather than relying on the teacher's knowledge and textbooks to solve problems. The role of the teacher is to recognize students' prior conceptions and to design activities that build upon the students' knowledge, using strategies such as experimentation, problem-solving, reflection, concept-mapping, and dialogue to create deep knowledge and understanding (Brandon \& All, 2010). 


\section{Reform-Oriented Teaching Practices in Learning Science}

The term "reform-oriented teaching" describes a collection of instructional practices that are designed to engage students as active participants in a studentcentered learning environment and in inquiry-based activities that enhance the development of complex cognitive skills and processes (Le et al., 2009; Manno, 2011). Bektas and Taber (2009) described student behaviors that an observer expects to see in a constructivist classroom: students who are active and heavily involved in classroom discussion and in a range of activities; students who ask as well as answer questions; and students who give extended answers and explanations in dialogue with the teacher. Most of the work in the classroom is collaborative. Scientific ideas are linked to learners' own experiences and concerns. Assessment tasks are integrated into learning and are designed to generate deep understanding rather than to produce reliable data on surface features of learning. Reform-oriented teachers work as facilitators, helping their students construct knowledge and understanding through inquiry-based activities that engage students in learning communities where ideas are shared and valued (Sampson, Enderle, \& Grooms, 2013).

Measuring Reform-Oriented Teaching Practices. In this section, we present studies that have proposed measurable elements of reform-oriented instructional practices (RTPs) and the methods used to collect data on classroom reform-oriented instruction. Sawada et al. (2002) developed the Reformed Teaching Observation Protocol (RTOP) to provide a strong evidential basis for measuring the impact of a given reform. The RTOP contains three scales: lesson design and implementation, content, and classroom culture (Sawada et al., 2002). The researchers concluded that RTOP is strongly predictive of how much students learn in their classrooms and that it helps in making holistic judgments about features of lesson design and classroom culture (Sawada et al., 2002).

Yager, Akcay, Dogan, and Yager's (2013) instrument includes items to measure teaching practices, teacher-student interactions, and student-student interactions. They targeted science/technology/society (STS) reform-based classes implemented in Iowa. The instrument items used for their study were developed from videotaped classroom observations of science teachers who were involved with STS groups (Yager et al., 2013). Focusing on the concept of inquiry-oriented teaching, Borko, Stecher, and Kuffner (2007) created ten dimensions of RTPs for teaching science based on the NRC's (1996) standards. These are:
1. Grouping
2. Structure of lessons
3. Use of scientific resources
4. Hands-On
5. Inquiry
6. Cognitive depth
7. Scientific discourse community
8. Explanation/justification 


\section{Assessment}

\section{Connections/applications}

Other researchers have focused on developing a reliable and valid instrument that can help to overcome conceptual and technical challenges associated with measuring classroom instruction. Significantly, Martinez, Borko, and Stecher (2012) designed an instrument that combines artifact collection (lesson plans, handouts, rubrics, readings, worksheets, assignments, student homework, projects, portfolios, vignettes) and teachers' self-reporting (logs) and called it the Scoop Notebook. The authors contended that the combination of artifacts and teachers' self-reporting is useful for measuring instructional practices with reliability similar to measures based on classroom observation (Martinez et al., 2012).

\section{Defining Teachers' Pedagogical Beliefs}

In educational settings, the convictions, philosophies, understandings, and views that individuals hold about teaching and learning are referred to as pedagogical beliefs (Haney, Lumpe, \& Czerniak, 2003). According to Kagan (1992), teachers' beliefs are "tacit, often unconsciously held assumptions about students, classrooms, and the academic material to be taught" (p. 65). Research has shown that beliefs can guide instructional decisions and influence classroom practices (Jones \& Carter, 2007; Pajares, 1992). Fives and Buehl (2012) identified three roles that beliefs serve related to teachers' practice: filters for interpretation, frames for defining problems, and guides for practice (Figure 1).

Figure 1. The Roles of Teachers' Beliefs

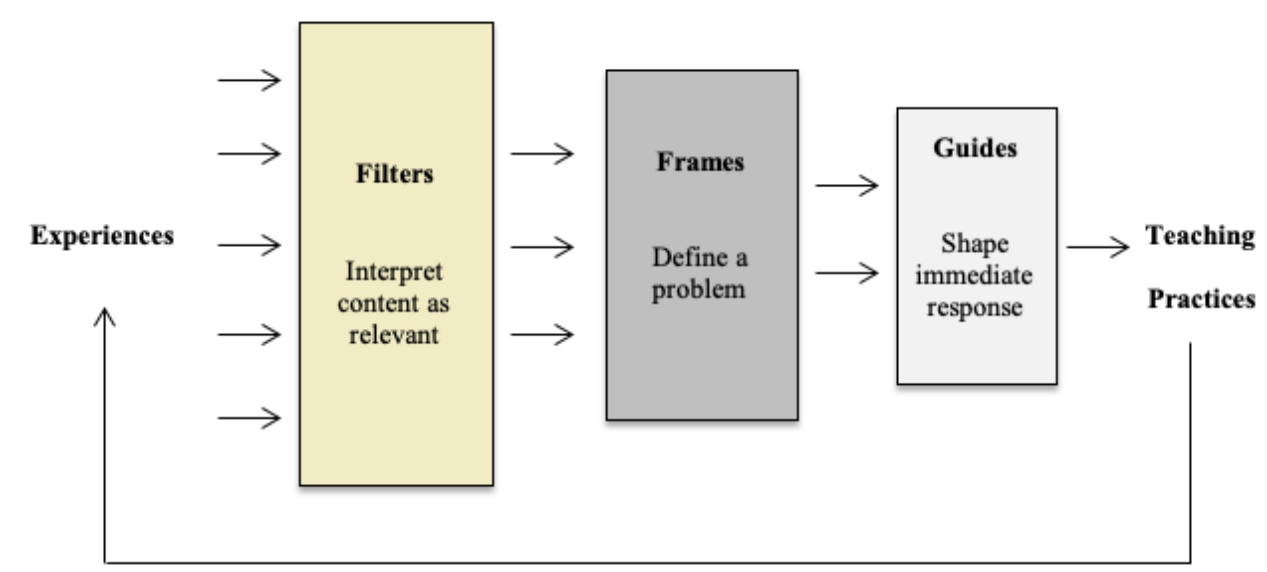

Source: Fives \& Buehl (2012, p. 478).

When implementing a curriculum reform, teachers' beliefs about teaching (as student- or teacher-centered), their knowledge, and the learners themselves will either support or undermine the implementation of the new initiative (Fives \& Buehl, 2016). Therefore, it is crucial to examine and address teachers' epistemic beliefs (beliefs about knowledge) and pedagogical beliefs (beliefs about teaching and learning) in light of the reform initiative. Traditional pedagogical beliefs are 
associated with behaviorism and are characterized by teacher-centered instruction. In contrast, constructivist pedagogical beliefs are grounded in constructivism or socio-constructivism and are characterized by student-centered instruction (Deng, Chai, Tsai, \& Lee, 2014). Teachers holding student-centered beliefs act as facilitators and use a process of teaching that is responsive to the needs of learners. They promote students' construction of meaning and understanding based on the students' prior knowledge and personal experiences. They create learning environments that facilitate students' active sense-making and use formative assessment to making teaching decisions (Tondeur, van Braak, Ertmer, \& Ottenbreit-Leftwich, 2017).

\section{Relationship between Pedagogical Beliefs and Implementation of the Constructivist Curriculum}

Research has shown that teachers' beliefs about the teaching and learning of science, the reform curriculum, and their own roles alter and "filter" innovative practices, even as teachers claim publicly to implement reform-oriented practices (Sampson et al., 2013). Feldman (2002) found that high-school teachers implemented a reform-driven physics curriculum in very different ways that reflected their beliefs. Feldman explained that the teacher whose beliefs were best aligned with those of the reform-based curriculum fully adopted the curriculum. The teacher who believed that his role was to promote interest in physics only partially implemented the reform-based curriculum, eventually abandoning it because it did not fit well with his beliefs. These findings support Cronin-Jones's (1991) conclusions that when middle-school science teachers firmly believed that science is a body of factual content and students lack the required skills for independent learning, the teachers' teaching practices were not compatible with the given reform-oriented constructivist curriculum.

Roehrig and Garrow (2007) confirmed that teachers' beliefs about what students should learn and students' capability to learn are critical factors in the implementation of reform-oriented practices. Furthermore, it has been shown that the teachers tend to overstate their level of implementation of reform-based practices, despite a lack of knowledge, for the sake of "social desirability." Yildirim and Kasapoglu (2015) reported that Turkish teachers who held positive views of the constructivist student-centered curriculum tended to believe that they implemented constructivist teaching and learning practices more frequently. However, the researchers indicated that the teachers did not fully endorse a constructivist curriculum due to their lack of knowledge about curriculum content, learner-centered instruction and technology, and non-traditional assessment.

\section{Teachers' PCK for Teaching a Reform-Oriented Curriculum}

The concept of PCK was introduced by Shulman (1986), who defined it as "the blending of content and pedagogy into an understanding of how particular topics, problems, or issues are organized, represented, and adapted to the diverse interests and abilities of learning, and presented for instruction" (p. 8). Grossman 
(1990) broadened Shulman's (1987) definition of PCK by proposing four components: (a) knowledge and beliefs about the purposes of teaching a subject; (b) knowledge of students' understanding, conceptions, and misconceptions; (c) knowledge of the curriculum; and (d) knowledge of instructional strategies. Cochran, King, and DeRuiter (1991) defined PCK from a constructivist perspective as "the manner in which teachers relate their pedagogical knowledge to their subject matter knowledge in the school context, for the teaching of specific students" (p. 1). Park and Oliver (2008) identified the following five elements of PCK for science teaching: (a) teachers' beliefs about and orientations to science teaching, (b) knowledge of students' understanding of science, (c) knowledge of the science curriculum, (d) knowledge of instructional strategies and representations for teaching science, and (e) knowledge of assessments of science learning. Rozenszajn and Yarden (2014a) argued that PCK is topic-specific, personal, and situation-specific.

Several studies have investigated the relationship between teachers' PCK and its impact on teaching. For instance, Carlsen (1987) suggested that low levels of PCK are associated with the frequent use of simple factual recall questions. In regard to biology education, Rozenszajn and Yarden (2014a) observed that biology teachers often indicate that they are more focused on acquiring content knowledge (CK) rather than PCK to stay up-to-date with the most recent developments in the field of biology. In another study, Rozenszajn and Yarden (2014b) indicated that mathematics teachers viewed CK and PCK as related components, whereas biology teachers tended to view CK as separate from PCK. The authors suggested that biology teachers may invest time and energy to keep up-to-date with developments in biological knowledge, thus neglecting the need to update their PCK (Rozenszajn \& Yarden, 2014b).

Park and colleagues (2011) examined the relationship between a teacher's PCK level and the extent to which her/his instruction was reform-oriented. The results showed that a teacher who has more developed PCK is more likely to implement higher levels of reformed science instructional practices. Furthermore, it has been reported that regardless of mathematics teacher beliefs, the lack of knowledge and understanding limits teachers' ability to align the curriculum and instruction with students' needs (Lui \& Bonner, 2016). On the other hand, research indicates that many mathematics teachers with strong content knowledge tend to implement traditional instructional methods (Mewborn, 2001). Wilkins (2008) justified this phenomenon that some teachers with strong content knowledge refer their success to the ways they were taught. If they were taught using traditional methods, it is likely that they consider these methods as effective for teaching mathematics and will tend to use traditional methods.

\section{Implementation of the Reform-Oriented Science Curriculum in Oman}

Research shows that Omani science teachers have encountered challenges in implementing inquiry-based learning for reasons related to a lack of time and resources and large class sizes (Ambusaidi \& Al-Balushi, 2015). Meanwhile, research investigating Omani science teachers' beliefs about using inquiry-based 
teaching and cooperative learning shows that teachers hold positive perceptions of inquiry-based learning (Al-Harthi, 2008). Al-Balushi and Al-Rawahi (2011) examined Omani physical education and science teachers' beliefs about cooperative learning. They reported that Omani teachers showed weak intentions to use cooperative learning in their classrooms.

To understand science teachers' pedagogical beliefs about constructivistbased teaching, Ambusaidi and Al-Balushi (2012) conducted a longitudinal study targeting prospective science teachers. They examined College of Education at Sultan Qaboos University teachers' beliefs after the teachers had completed the first science-methods course and again after they had completed the second science-methods course and the practicum. The results showed that the prospective science teachers tended towards using a teacher-centered approach even after having the opportunity to learn about different student-centered teaching practices. The researchers explained that this tendency is due to prospective teachers' own experiences as students and common practices in schools and colleges (Ambusaidi \& Al-Balushi, 2012).

Recently a comprehensive joint study conducted by Oman's Ministry of Education and the World Bank (2012) aimed to evaluate the Omani educational system after the reform. The study findings pinpointed that teachers lack the PCK necessary to implement a student-centered learning approach. Teachers' insufficient level of PCK was attributed to minimal emphasis on pedagogical skills and the limited use of practical training during pre-service teacher education. Furthermore, teacher-educators did not have any teaching experience in school settings (MOE \& World Bank, 2012).

As these studies suggest, the implementation of the constructivist science curriculum in Oman has been problematic due to factors related to teachers' beliefs and their lack of pedagogical content knowledge. Therefore, it is necessary to investigate how Omani biology teachers' pedagogical beliefs and their PCK predict their levels of implementation of constructivist instructional practices.

\section{Methods}

In investigating the proposed questions, we employed an ethnographic approach to data analysis. We combined classroom observations, learning artifacts, and semi-structured interviews to generate rich data.

\section{Research Sample}

Research Site. The study was focused on the Omani province of Muscat. The focus was on Post-BES public schools (grades 11-12), because biology is taught as a discrete subject at this level. According to the Ministry's data 2017-2018 there were 34 public Post-BES schools employing 55 biology teachers in Muscat (Omani and non-Omani teachers) during 2017-2018. The selection criteria for schools and teachers included in this study were based on the number of students studying biology in a given school. Schools with at least 20 biology students each 
were preferred. In addition to the number of students, factors such as gender, location, and student achievement levels were considered. Ultimately twelve schools were involved in the study (five all-boys' schools and seven all-girls' schools); as shown in Table 1 below. It is worth noting that students' levels of achievement were compared in two consecutive years (2016 and 2017). Hence, we selected the all-boys' and all-girls' schools with the highest and lowest average percentages in each of the states to provide a better representation of teachers' beliefs and practices.

Table 1. Sample of Schools Visited

\begin{tabular}{|l|c|c|c|c|c|c|}
\hline \multirow{2}{*}{ State } & \multicolumn{2}{|c|}{$\begin{array}{c}\text { Total Number of } \\
\text { Schools }\end{array}$} & \multicolumn{4}{|c|}{ Number of Schools Visited } \\
\cline { 2 - 7 } & $\begin{array}{c}\text { All } \\
\text { boys' } \\
\text { Schools }\end{array}$ & $\begin{array}{c}\text { All } \\
\text { girls, } \\
\text { Schools }\end{array}$ & $\begin{array}{c}\text { All } \\
\text { boys' } \\
\text { Schools }\end{array}$ & $\begin{array}{c}\text { Level of } \\
\text { achievement }\end{array}$ & $\begin{array}{c}\text { All } \\
\text { girls' } \\
\text { Schools }\end{array}$ & $\begin{array}{c}\text { Level of } \\
\text { achievement }\end{array}$ \\
\hline Mutrah & 2 & 2 & 1 & High & 1 & High \\
\hline Bowsher & 1 & 2 & 1 & High & 2 & High \\
\hline A'Seeb & 4 & 5 & 1 & High & 2 & High \\
& 1 & 1 & 1 & Low & 1 & Low \\
\hline AlAmerat & 1 & 1 & 1 & Low \\
\hline
\end{tabular}

\section{Participants}

Purposeful sampling was utilized to select research participants. Biology teachers were selected based on their gender and their students' achievement level on national tests. Fourteen teachers were included in this study: five males and nine females as more female teachers than expected were willing to participate (Table 2). Pseudonyms were used to represent all participants. 
Table 2. Demographics of the Biology Teachers Involved in the Study

\begin{tabular}{|c|c|c|c|c|c|}
\hline Teacher & Gender & Age & $\begin{array}{l}\text { Years of } \\
\text { Experience }\end{array}$ & $\begin{array}{c}\text { Classes and Subjects } \\
\text { Taught }\end{array}$ & Education \\
\hline KM & $\mathrm{F}$ & 30 & P & $\begin{array}{c}\text { Biology } \\
\text { (Grades 11-12) }\end{array}$ & $\begin{array}{l}\text { B.Ed major biology- Nizwa } \\
\text { University }\end{array}$ \\
\hline LS & $\mathrm{F}$ & 32 & 6 & $\begin{array}{l}\text { Biology } \\
\text { (Grade 12) }\end{array}$ & $\begin{array}{c}\text { B.Sc major biology- Higher } \\
\text { College of Technology } \\
\text { Diploma in Education- } \\
\text { UAE }\end{array}$ \\
\hline $\mathrm{ZS}$ & $\mathrm{F}$ & 35 & 10 & $\begin{array}{c}\text { Biology } \\
\text { (Grades 11-12) }\end{array}$ & $\begin{array}{c}\text { B.Sc major biotechnology- } \\
\text { Sultan Qaboos University } \\
\text { Diploma in Education- } \\
\text { SQU }\end{array}$ \\
\hline WL & F & 45 & 21 & $\begin{array}{l}\text { Science, biology, } \\
\text { science and the } \\
\text { environment, science } \\
\text { and technology } \\
\text { (Grades 5-12) }\end{array}$ & $\begin{array}{l}\text { B.Sc major biology- Sultan } \\
\text { Qaboos University } \\
\text { Diploma in Education } \\
\text { College of Muscat }\end{array}$ \\
\hline MK & F & 48 & 26 & $\begin{array}{l}\text { Science and biology } \\
\text { (Grades 4-12) }\end{array}$ & $\begin{array}{c}\text { B.Ed major biology- Sultan } \\
\text { Qaboos University }\end{array}$ \\
\hline RH & F & 29 & 7 & $\begin{array}{c}\text { Biology } \\
\text { (Grades 11-12) }\end{array}$ & $\begin{array}{l}\text { B.Ed major biology- Sohar } \\
\text { University }\end{array}$ \\
\hline HM & $\mathrm{F}$ & 33 & 11 & $\begin{array}{l}\text { Biology, science and } \\
\text { the environment, and } \\
\text { science and technology } \\
\text { (Grades 11-12) }\end{array}$ & $\begin{array}{l}\text { B.Ed major biology- Sultan } \\
\text { Qaboos University }\end{array}$ \\
\hline $\mathrm{AR}$ & $\mathrm{F}$ & 29 & 6 & $\begin{array}{l}\text { Biology, science and } \\
\text { technology, and } \\
\text { science (Grades 8-12) }\end{array}$ & $\begin{array}{l}\text { B.Sc major biotechnology- } \\
\text { Sultan Qaboos University } \\
\text { Diploma in Education- } \\
\text { Ajman University }\end{array}$ \\
\hline MG & $\mathrm{F}$ & 25 & 3 & $\begin{array}{c}\text { Biology } \\
(\text { Grades 11-12) }\end{array}$ & $\begin{array}{c}\text { B.Ed major biology- Sultan } \\
\text { Qaboos University }\end{array}$ \\
\hline $\mathrm{MN}$ & M & 47 & 27 & $\begin{array}{l}\text { Biology } \\
\text { (Grade 12) }\end{array}$ & $\begin{array}{l}\text { B.Ed major biology (2010)- } \\
\text { Rustaq College of } \\
\text { Education Diploma (1992)- } \\
\text { College of Education- } \\
\text { Muscat }\end{array}$ \\
\hline QF & M & 35 & 12 & $\begin{array}{c}\text { Biology } \\
(\text { Grade 12) } \\
\text { and Science } \\
(\text { Grade 10) }\end{array}$ & $\begin{array}{l}\text { B.Ed major biology (2008)- } \\
\text { Sultan Qaboos University }\end{array}$ \\
\hline $\mathrm{OZ}$ & M & 32 & 11 & $\begin{array}{l}\text { Biology } \\
(\text { Grade 12) }\end{array}$ & $\begin{array}{l}\text { B.Ed major biology (2009)- } \\
\text { Sur College of Education }\end{array}$ \\
\hline AS & M & 31 & 9 & $\begin{array}{l}\text { Biology and science } \\
\text { and the environment } \\
\text { (Grade 12) }\end{array}$ & $\begin{array}{l}\text { B.Ed major biology(2010)- } \\
\text { Rustaq College of } \\
\text { Education }\end{array}$ \\
\hline MM & M & 44 & 15 & $\begin{array}{l}\text { Biology and science } \\
\text { and the environment } \\
\text { (Grade 12) }\end{array}$ & $\begin{array}{l}\text { B.Ed major biology and } \\
\text { earth sciences- Sultan } \\
\text { Qaboos University }\end{array}$ \\
\hline
\end{tabular}




\section{Data Collection}

Classroom Observations. The reform-oriented practice measurement instrument used for this study was developed based on a literature review of existing reform measurement instruments (Appendix A). The instrument was designed to encourage the use of multiple data-collection methods beyond classroom observations to obtain a more thorough picture of teachers' practices and beliefs. The validity of the instrument was ensured by consulting with a group of educators from the Ministry of Education, including the chief and senior supervisors for science subjects and an assessment specialist. Furthermore, four twelfth-grade biology teachers validated the instrument. They all approved of the instrument and indicated its alignment with constructivist theory practices and the Post-BES reform curriculum.

The classroom observations were conducted by two researchers who are familiar with the Omani education context and have substantial experience with teaching and supervision. The inter-rater reliability was obtained by conducting two preliminary classroom observations together and discussing how both researchers rated the teacher on each item included in the instrument and to what extent the item description was helpful. The inter-rater reliability was $94 \%$. Observations were conducted during March and April 2018. Due to the context and topic specificity of PCK, all observations conducted centered on the same unit of instruction (Unit 4: Heredity). All teachers from the sample were observed once. Afterward a second round of observations was conducted. The total number of classroom observations was 24 .

Pre-Observation and Post-Observation Reflections. Each teacher was asked to reflect on each of their observed lessons twice, first before execution and then after execution. The aim was to gain insight into the teachers' perceptions of their CK, PCK, and the relationship between their PCK and classroom practices. The pre-observation form (Appendix B) asked the teachers what they took into consideration in planning the observed lesson. On the post-observation form (Appendix C), the teachers were asked to provide an analysis of the observed lesson. The total number of forms collected was 48 .

Teaching and Learning Artifacts. The participating teachers were asked to provide samples of students' work, such as worksheets, notebooks, quizzes, tests, laboratory reports, assignments, and projects. The teachers were also asked to provide teaching artifacts such as lesson plans, task sheets, and class activities. The artifacts served to support and expand upon the observations and the responses of the participants during interviews. All student artifacts collected were anonymized to protect students' privacy.

Semi-Structured Interviews. All interviews were conducted in the teachers' schools and after the second classroom visit had taken place for each teacher. The interviews started with the Curriculum Platform Q-sort (Badiali, 2005; Appendix D). The Curriculum Platform Q-sort asked the participants to order various 
statements in four groups (aims of education, nature of knowledge, teacher's role, and curriculum purpose) according to their beliefs. The teachers were then asked to elaborate on their order of statements and choices. The interview guide includes informational questions about participants' demographics and questions about educational philosophy orientation. The questions were broad and open-ended and centered on the participants' practices, views, and justifications of their views and practices regarding the reform-based biology curriculum. Each interview took between 25 and 40 minutes.

All interviews with the biology teachers were conducted in the interviewees' first language, which is Arabic. The interviews were audio-recorded after obtaining the participants' permission. The audio recordings were then transcribed using the 1:09:02.2 version of Express Scribe Transcription Software. All the transcribed interviews were subsequently translated from Arabic into English. Follow-up interviews were then conducted by phone or email with all the participants for member checks and to clarify some of the points they highlighted.

\section{Data Analysis}

We employed Braun and Clarke's (2006) thematic analysis approach to identify, analyze, and report themes within the data. We presented the findings and emerging themes and subthemes by discussing evidence from multiple data sources (Creswell \& Plano Clark, 2011). Theoretical codes derived from constructivist instruction were used to analyze teachers' implementation of the curriculum. Additionally, inductive coding was employed by carrying out participant-oriented data analysis to allow for emerging themes and in-depth analysis.

For each code, we contrasted each participant's practices with their beliefs in order to detect how their espoused beliefs align with their enacted beliefs and practices. Codes were grouped and interpreted based on their frequency. Afterwards, we grouped similar codes into initial themes. Additionally, we compared data segments from different participants to uncover the extent to which participants who hold the similar beliefs have similar classroom practices.

\section{Trustworthiness and Ethical Considerations}

We employed Lincoln and Guba's (1985) trustworthiness criteria-credibility, transferability, dependability, and confirmability- to establish the study's research validity and reliability. We utilized multiple methods of data collection (classroom observations, interviews, field notes, teachers' reflection, and artifacts) for triangulation. We designed the data-collection procedures and data-analysis methods based on methods that had been successfully utilized in previous comparable studies. Hence, we developed thick and detailed descriptions of the teachers' experiences in an attempt to convey the actual situation.

For greater transparency, we conducted member checks to ensure the accuracy of the data collected from the interviews (Creswell \& Plano Clark, 2011). In addition, we implemented the strategies suggested by Bogdan and Biklen 
(2007) and Maxwell (2013) to ensure that the study was carried out ethically. We obtained individuals' verbal consent to participate in the study. Most importantly, the study adhered to the ethical requirements of The Pennsylvania State University's Institutional Review Board (IRB) and the Omani Ministry of Education's research regulations.

\section{Limitations of the Study}

The limitations are related to the methods used. Selecting schools based on students' achievement on national tests was difficult due to differences in school populations. In addition, school data suggesting that girls outperform boys led to a sample consisting exclusively of high-achieving girls' schools. Thus, the selection criteria needed to be adjusted to ensure the inclusion of both all-boys' and all-girls' schools, as well as schools of varying achievement levels and from different states in Muscat. Purposeful sampling rather than the random selection of participants was employed. Hence, the findings of this study may have limited generalizability. Furthermore, the value of the data depends on the participants' decisions to provide responses that represent their true beliefs rather than responses that are simply socially desirable. For such reasons, the triangulation of data-collection methods was used in this study.

\section{Results}

\section{Teachers' Pedagogical Beliefs}

The teachers' pedagogical beliefs are discussed based on their ordering of the statements in the Curriculum Platform Q-sort and their responses during the interviews (Table 3). Three teachers (OZ, HM, AR) held progressivist views. Three of the teachers (MK, MN, QF) held social reconstructionist views. Two teachers held beliefs that aligned equally with progressivism and reconstructionism. This indicates that a total of eight teachers held beliefs that aligned with constructivism. Two teachers (AS, MM) held perennialist views. Two other teachers (LS, RH) held mixed beliefs that aligned with both critical theory and progressivism. One teacher (WL) held mixed beliefs that aligned with both essentialism and perennialism. When teachers elaborated on their pedagogical beliefs in terms of knowledge, students' learning, their role in the classroom, and the curriculum, the following themes emerged. 
Table 3. Teachers' Ratings on the Curriculum Platform Q-sort

\begin{tabular}{|l|c|}
\hline Teacher & Orientation \\
\hline MN & Reconstructionism \\
\hline MK & Reconstructionism \\
\hline QF & Reconstructionism \\
\hline OZ & Progressivism \\
\hline HM & Progressivism \\
\hline AR & Progressivism \\
\hline ZS & Progressivism \& Reconstructionism \\
\hline KM & Progressivism \& Reconstructionism \\
\hline RH & Progressivism \& Critical Theory \\
\hline LS & Critical Theory \& Progressivism \\
\hline AS & Perennialism \\
\hline MM & Perennialism \\
\hline WL & Essentialism \& Perennialism \\
\hline
\end{tabular}

\section{Theme 1: Teachers Believed that Students Construct Knowledge Based on Pre-existing Knowledge}

Eleven of the teachers interviewed (OZ, AR, LS, ZS, HM, MM, AS, MN, $\mathrm{QF}, \mathrm{KM}$, and $\mathrm{MK}$ ) believed that knowledge should focus on growth and development and that it is constructed through active and relevant learning experiences. Nine of them held beliefs that aligned with progressivism and/or reconstructionism, while two held beliefs that aligned with perennialism. OZ explained why he thought that knowledge is best acquired through active learning by saying:

"I try to implement active learning as I could...In active learning the student learns indirectly. In both methods (traditional and active learning) he achieves the learning objectives, but in active learning he achieves them while he enjoys learning. In traditional methods its compulsory to get the grade"

On the other hand, WL and RH believed that knowledge should focus on essential skills and academic subjects, mastery of concepts, and principles of subject matter. WL held beliefs that aligned equally with essentialism and perennialism, while RH held beliefs that aligned equally with critical theory and progressivism.

\section{Theme 2: Teachers Believed that Students Learn by Engaging in Inquiry and Problem-solving and by Connecting Concepts to Real-world Applications}

The majority of the teachers agreed that their students learn better when they are actively engaged in inquiry-based leaning, cooperative learning, and problemsolving. They elaborated on this by providing examples of how their students learn biology best, such as by making connections with the real world, applying their knowledge, using visual representations, engaging in dialogue and discussion with peers, investigating, brainstorming, and doing hands-on activities (Table 4). 
Table 4. Ways Students Best Learn Biology, as Reported by Teachers

\begin{tabular}{|l|c|}
\hline Teacher & Best learning methods \\
\hline WL & Active learning \\
\hline MK & Dialogue and conversation \\
\hline KM & Connections to real world, cooperative learning \\
\hline AR & Inquiry, research, hands-on activities \\
\hline HM & Connections to real world, visual clues \\
\hline RH & Connections to real world, visual clues \\
\hline ZS & Inquiry, connections to real world, research \\
\hline LS & Dialogue and conversation, visual clues \\
\hline MM & Active learning, inquiry, research, brainstorming \\
\hline MN & Inquiry, research, cooperative learning, learning stations \\
\hline AS & Connections to real world, ICT \\
\hline OZ & Role play, visual clues \\
\hline QF & Active learning, discussions with peers \\
\hline
\end{tabular}

\section{Theme 3: Teachers believed that their Role is to Guide and Facilitate Students' Learning}

The majority of the teachers (MM, HM, AR, KM, RH, OZ, QF, ZS, AS, MK, and WL) believed that teachers are guides for problem-solving and scientific inquiry. They asserted that the teacher should help students solve problems and develop into inquisitive and curious learners. The teacher should facilitate students' learning by creating a safe environment for interaction and differentiating learning in response to students' individual differences. The teacher should teach students how to learn. The teachers explained their views as follows:

HM: "In the past the teacher was the knowledge dispenser who presents information and the student is the listener only. But now the student should be the center of the educational process and we should give her opportunities to try and explore and solve problems...If the teacher acts as a guide and the student do research and inquiry, the teacher would be able to know to what extent the student has acquired the knowledge and skills"

ZS: "The teacher is no longer the only source of knowledge. So, the teacher should put some effort and much care to create and train this generation to be curious toward learning and become critical thinkers"

\section{Theme 4: Teachers had Different Perspectives on the Curriculum's Definition and Purpose, which were influenced by their Pedagogical Beliefs}

The teachers approached the curriculum from different perspectives. Six teachers (KM, AR, QF, AS, MK, and RH) believed that the curriculum should focus on the students' interests, involve the application of knowledge to authentic problems, and connect knowledge to real-world applications. 
KM: "If the curriculum is not centered on students' interests than it will be just an abstract subject that the student can't accept. There has to be research and inquiries that the students do to connect knowledge with the real world"

However, five teachers (MM, WL, OZ, ZS, and LS) believed that the curriculum should center on essential skills and major content areas. HM and MN thought that the curriculum should center on social problems:

HM: "I believe that the student should be aware of the problems around her to identify her role in the future. She should connect the curriculum with the real world and be aware of her society issues and problems, so she can contribute in the future in solving these problems"

Interestingly, the teachers defined the student-centered curriculum differently. Some of the teachers (MN, MM, and OZ) simply said that the student should be the focus of teaching and learning. Other teachers (WL, ZS, KM, LS, HM, QF, MK, $\mathrm{AR}$, and $\mathrm{RH}$ ) defined it as active learning, where the teacher acts as a guide and the student does all the work and engages in research to gain knowledge and does not expect the teacher to be the only source of knowledge. Some of the definitions of the student-centered curriculum/learning that the teachers gave are as follows:

AR: "In student-centered learning we focus on inquiry, research, self-learning and team-work"

QF: "The teacher should guide and supervise students learning in the class, while the student should research for knowledge that he could get it through some probing and leading questions. Or by solving problems that the teacher design for the student to inquire and investigate the solutions and discuss his findings with his peers"

In addition to possessing different definitions of student-centered learning, teachers described active learning differently. For instance, WL said that she has implemented active learning by motivating students, providing incentives, and employing brainstorming and role play. She asserted that she had implemented active learning in the class that the researcher observed. She randomly chose a student to come at the board. Then the student randomly picked a question to solve on the board. In contrast, HM believed that in active learning, the student should do all the work and engage in research to gain knowledge under the teacher's guidance. She described active learning by saying:

"It (student-centered learning) should be like what I saw in the workshop about active learning. Right from the beginning the teacher (the trainer) let the students (the trainees) do everything. She treated us like her students, and she explained how the students should work and do all the tasks. She was our guide and discussed with us our mistakes. We did concept maps and she helped us get to the final conclusion by discussing our findings and asking questions. When we faced a problem, she helped us identify it and discussed 
with us the solutions. We worked in groups"

\section{Teachers' PCK}

In this study, we employed Park and Oliver (2008) definition of teachers' PCK. First, we shed light on teachers' level of confidence about their CK and PCK. Then we discuss to what extent the teachers believed their PCK has shaped their implementation of the curriculum.

Theme 5: Teachers perceived that they have Strong Content Knowledge (CK) but that they Lack the Pedagogical Content Knowledge (PCK) Necessary to Teach the Reform-oriented Curriculum

All teachers showed confidence in their CK and described their college-level content preparation to be strong, in-depth, relevant, and applicable to the real world. AR studied biotechnology in college. She explained that her strong preparation in the applications of biotechnology enabled her to substitute some of the textbook experiments that she thought were not useful for achieving the learning goals with other experiments. She introduced new experiments that were easy to conduct, interesting, and helpful in achieving the learning goals. Teachers who had significant teaching experience and had taught the old system's curriculum (MK and WL) claimed that they had strong CK due to their extensive experience and their time teaching the old curriculum, as the old curriculum was more comprehensive and covered topics in depth. WL compared her CK with her PCK, saying:

"With respect to content knowledge yes (confident), but not with pedagogical knowledge. We have stronger background, but the new teachers are better prepared in the use of technology and the use of computers, ipads, and smart applications. They apply them in the lessons which is good for this generation. We are somehow hesitant to use technology. But the new teachers come to us on the basics such as how to prepare the lesson, the content knowledge, teaching methods because of our long experience"

\section{Theme 6: Teachers Sought to improve their PCK to Effectively Implement the Reform-oriented Curriculum}

Knowledge of Instructional Strategies. The teachers did not express the same level of confidence about their PCK. Most of them indicated that they have developed better PCK with experience and by engaging in independent learning. They indicated that their pedagogical preparation was suitable at the time they graduated when only traditional methods of teaching were accepted in schools. With the shift towards student-centered learning and the expansive use of ICT, however, the teachers recognized that they needed to stay up to date with the new teaching and learning methods.

MK: "When I graduated the teaching methods were few and simple in the 
nineties. There was no cooperative learning, team-work, or active learning. Now there are many new methods and the teacher should learn these methods and stay up to date"

One teacher (AR) said her preparation in education did not include any courses in teaching methods but that she had received support from her supervisor and learned teaching methods by observing other teachers teaching or attending workshops:

"In terms of teaching methods, I need more experience I have only 3 years of experience. At SQU I did not study education but outside the country, but there was no course for teaching methods. So, I faced challenges when I started teaching. My supervisor helped me by conducting exchange visits with my peers inside and outside the school and sometimes she showed me how to teach by observing her teaching the class... I learned teaching methods also by self-directed PD through reading and research and observing other biology teachers' lessons"

The teachers claimed that in college they had learned traditional instructional methods that depended on lectures, memorization, recitations, and discussions. However, they relied on self-directed learning, ongoing professional development, supervisors, collaboration with peer teachers, lessons learned from teaching, and research to keep up to date in terms of CK and PCK:

QF: "My preparation in college was in the traditional style lectures, memorization, and recitation. I was a passive recipient of knowledge and the teacher was always the dispenser of knowledge. I keep researching, inquiring for knowledge so I don't face challenges in terms of my level of confidence about myself, the curriculum, or how to deal with knowledge to make it easy to understand and accessible to students. At the same time, I continuously learn from my students on how they better learn or their perceptions about what they are learning, and I consider this is one of the ways that helped me grow"

Knowledge of Students' Understanding. The teachers reported that they used multiple and different indicators to identify effective learning moments. Most of the teachers described moments of effective learning as moments when their students were able to apply the concepts, solve different levels of problems, and achieve learning goals independently or in groups. For example, OZ described a moment of effective learning when his students provided evidence to support their answers and they were able to create challenging questions and debate with other students. QF described a moment of effective learning when he challenged his students to evaluate him and correct his intended mistakes. On the other hand, AS, MM, LS, and RH considered students answering the teacher's questions and repeating the answers as indicators of effective learning. Interestingly, those teachers' beliefs aligned with perennialism, critical theory, or progressivism. 
In the majority of the lessons observed, the teachers indicated that they change their teaching methods from one section to another. The teachers explained that they change their teaching methods because of individual differences, students' levels, students' preferences for learning, students' interactions, selfreflection on teaching, and allotted time. All these teachers held beliefs that aligned with progressivism. AS indicated that he does not change his teaching methods from one classroom to another because the learning objectives are the same and problem-solving is the best method to teach the topic. His beliefs aligned with perennialism.

Knowledge of the Curriculum. In the classrooms observed, the teachers showed good knowledge of the curriculum. They indicated that they have to enrich and teach it in-depth. They emphasized that the curriculum is dense in terms of the number of topics included but that each topic is covered superficially.

Knowledge of Learning Assessments. Three teachers (OZ, QF, and WL) relied heavily on formative assessment, while three other teachers (MN, MM, and ZS) used it only occasionally to assess students' learning. Most of the teachers thought that applications of concepts through problem-solving were sufficient to indicate that their students had learned the new concepts. Some teachers (MN, WL, OZ, ZS, and MM) adjusted the problems based on their students' performance. Both the teachers and students focused heavily on solving test-type problems and their concern was how to excel in solving problems to meet the testmarking criteria. However, only QF effectively used the data he gathered from formative assessment to adjust his teaching to address students' challenges with the application of the concepts. Teachers who used assessment effectively held beliefs that aligned with progressivism, reconstructionism, and perennialism.

Teachers' Espoused Beliefs. Most teachers expressed beliefs that aligned with student-centered learning. They emphasized the role of the student as that of an active learner who solves problems independently or in collaboration with others. They acknowledged that their students learn better by engaging in active learning and inquiry than by traditional teaching methods. Nevertheless, they pointed out that it was not always possible to implement active learning in the classroom because they had to prepare their students to obtain high scores on the tests.

\section{Teachers' Instructional Practices}

In this section we address the types of instructional practices implemented in the observed biology classrooms. We also discuss to what extent teachers' beliefs influence their decisions about the implemented instructional practices (Table 5). 
Table 5. Relationship between Teachers' Beliefs and Classroom Practices

\begin{tabular}{|c|c|c|}
\hline \multicolumn{2}{|c|}{ Instructional Practices } & Teachers' Beliefs \\
\hline \multicolumn{2}{|c|}{ Students' Pre-Existing Knowledge } & All Teachers \\
\hline \multicolumn{2}{|c|}{ Alternative Conceptions } & $\begin{array}{l}\text { Reconstructionism } \\
\text { Progressivism }\end{array}$ \\
\hline \multirow{7}{*}{$\begin{array}{l}\text { Instructional } \\
\text { Practices }\end{array}$} & Grouping & $\begin{array}{l}\text { Reconstructionism } \\
\text { Progressivism } \\
\end{array}$ \\
\hline & Hands-On Activities & Progressivism \\
\hline & Inquiry & Progressivism \\
\hline & Connections/Applications & $\begin{array}{l}\text { Reconstructionism } \\
\text { Progressivism (many) } \\
\text { Essentialism (one) } \\
\text { Critical Theory (one) } \\
\end{array}$ \\
\hline & Scientific Resources & $\begin{array}{l}\text { Progressivism (two) } \\
\text { Perennialism (two) }\end{array}$ \\
\hline & Assessments & $\begin{array}{c}\text { Reconstructionism } \\
\text { Progressivism }\end{array}$ \\
\hline & Cognitive Depth & $\begin{array}{l}\text { Reconstructionism (all) } \\
\text { Progressivism (all) } \\
\text { Essentialism (one) }\end{array}$ \\
\hline \multirow{2}{*}{$\begin{array}{l}\text { Active } \\
\text { Interactions }\end{array}$} & $\begin{array}{l}\text { Teacher-Student } \\
\text { Interactions }\end{array}$ & $\begin{array}{c}\text { Reconstructionism } \\
\text { Progressivism } \\
\text { Essentialism/ Perennialism (one) }\end{array}$ \\
\hline & Student-Student Interactions & $\begin{array}{c}\text { Reconstructionism } \\
\text { Progressivism }\end{array}$ \\
\hline
\end{tabular}

\section{Theme 7: All Teachers Considered Identifying Students' Pre-existing Knowledge to be Crucial to Learning}

All teachers indicated in their reflections that they take into consideration students' prior knowledge when planning lessons. This was confirmed in the interviews and observed in the classrooms. Another important factor that the majority of the teachers (RH, KM, AR, MN, AS, MM, and QF) indicated that they take into consideration students' individual differences. Teachers (HM, AR, MN, AS, and QF) highlighted the importance of connecting knowledge and concepts with real-world applications and students' lives.

AS: "It is important to connect the concepts and topic with pre-existing knowledge and knowing students' abilities and individual differences" ZS: "I take into consideration students' pre-existing knowledge, student's common misconceptions, the difficulties that students encounter based on my experience, and teaching methods that will help to clarify the topic and how to make sure the students have understood the concept" 


\section{Theme 8: Teachers with Beliefs that Aligned with Constructivism were Able to Identify and Challenge Students' Alternative Concepts}

Most teachers (10 out of 13) expressed awareness of the misconceptions or alternative concepts that their students might encounter when learning new concepts; this awareness was based on their previous experience teaching the concepts. Seven teachers (MN, OZ, AR, KM, ZS, AS, and MM) identified the alternative concepts they expected their students would struggle with when learning the new concepts. HM did not expect her students to have misconceptions that would interfere with learning the new concepts based on her experience. However, she was able to identify new alternative concepts that she did not know about during the lesson. She noticed her students were confused about "how the ovule is released," so she explained the new concepts, discussed the differences, and provided examples to help students see the differences.

The strategies used by the teachers to address alternative concepts varied, which might suggest that their beliefs influence their selection of strategies. Teachers who held both critical theory and progressivist beliefs (RH and LS) did not emphasize alternative concepts in their lesson plans and hence were not able to identify or address alternative concepts while teaching new concepts. Teachers who held beliefs that aligned with perennialism (AS, MM, and WL) and/or essentialism (WL) addressed the alternative concepts using strategies with the least potential to be effective (Hashweh, 1996), such as explaining, repeating, and asking questions. On the other hand, teachers who held beliefs that aligned with reconstructionism $(\mathrm{QF}, \mathrm{MN}, \mathrm{OZ}$, and $\mathrm{KM})$ and progressivism (OZ, $\mathrm{AR}, \mathrm{HM}, \mathrm{ZS}$, and KM) used the most potentially effective strategies (Hashweh, 1996), such as restructuring, giving examples, engaging students in cooperative learning, peer learning, research, and problem-solving.

\section{Theme 9: Teachers with Beliefs that Aligned with Constructivism Implemented Active and Inquiry-based Learning in their Classrooms}

Following the theoretical framework of this study, the instructional practices that characterize constructivism teaching practices include grouping, inquiry, hands-on activities, cognitive depth, assessments, applications and connections, and the use of scientific resources.

Grouping. Six teachers implemented group work during their lessons; three of the aforementioned six implemented it in both lessons observed. In terms of the group configuration, all six teachers confirmed that they had established rules for group work at the beginning of the semester and had divided students into heterogeneous groups for the whole semester or particular tasks. Three teachers (OZ, HM, and KM) spent all of the lesson time with the students working in groups. OZ used groups in both lessons observed for all or most of the lesson time, and there were fewer than five students in each group. In general, the beliefs of six of the teachers who implemented group work (KM, HM, AR, OZ, QF, and MN) aligned with progressivism and/or reconstructionism. 
Hands-on Activities. OZ was the only teacher who employed hands-on activities and investigations in which the students were physically involved. $\mathrm{He}$ acted as a guide to direct the students' analysis and conclusions. His beliefs aligned with progressivism.

Inquiry. Three teachers (OZ, KM, and $\mathrm{AR})$ allowed their students to complete investigations in groups and discuss scientific ideas, processes, and the results of their investigations with each other and their teacher. All three teachers held beliefs that aligned with progressivism.

Connections/Applications. The teachers attempted to make connections with the real-world context (8 teachers) and students' own experiences (10 teachers). The beliefs of eight teachers aligned with either or both progressivism and reconstructionism. Two teachers of the eight heavily focused on knowledge application in both lessons (OZ and HM). One teacher held beliefs that equally aligned with progressivism and critical theory, and another teacher held beliefs that equally aligned with perennialism and essentialism.

Cognitive Depth. In terms of the lesson structure, it was frequently observed that all teachers designed conceptually coherent lessons. Only one teacher (OZ) planned his lessons to engage the students in inquiry and to have the students' explorations precede the theoretical presentation. Ten teachers out of the fourteen visited emphasized making sense of scientific ideas and processes by asking "how" and "why" questions and encouraging students to think deeply. This was observed in the lessons of all teachers who held progressivist or reconstructionist beliefs. With regard to encouraging scientific thinking (analysis, reflection, and reasoning from evidence), four teachers (WL, HM, KM, and AR) moderately emphasized it. HM and AR focused on covering a few topics in depth in both lessons and making sure their students achieved the learning objectives before moving forward. It can be concluded that teachers with beliefs that aligned with progressivism and/or reconstructionism emphasized cognitive depth in their lessons.

Assessment. Eight teachers used formative and summative assessment to track students' achievement of learning objectives. All teachers' beliefs appear to have aligned with progressivism and/or reconstructionism, except for one teacher whose beliefs aligned equally with essentialism and perennialism. In terms of using data from formative assessments to inform pedagogical decision-making, it was observed that only one teacher $(\mathrm{QF})$ heavily used the data obtained to adjust his teaching. QF held beliefs that aligned with reconstructionism. The learning and teaching artifacts revealed that all teachers designed assessments and activities that represented both lower-order thinking skills (understanding and application) and higher-order thinking skills (analysis and evaluation). Teachers MK, AR and OZ employed projects and collaborative and team activities. Their beliefs aligned with either progressivism or reconstructionism. Only OZ used rubrics for students' projects and teamwork. 


\section{Theme 10: Teachers with Beliefs that Aligned with Constructivism Actively Engaged Students in Learning}

It was clear that all teachers who held beliefs that aligned with progressivism and reconstructionism encouraged and facilitated teacher-student interaction by using different and multiple means in the classroom. This level of interaction was not observed in the classrooms of teachers who held beliefs that aligned with perennialism (AS and $\mathrm{MM}$ ) or equally aligned with critical theory and progressivism $(\mathrm{RH})$.

The most common ways involved acknowledging the active participation of students (11 teachers), using students' answers that had personal value (10 teachers), and encouraging students to ask intriguing/useful questions (8 teachers).

Students' interaction with other students was not emphasized clearly in the classrooms observed. It seemed that teachers were mainly concerned about individual student learning at this stage. Interestingly, only teachers who held beliefs that aligned with progressivism and/or reconstructionism allowed interactions among students in their classrooms. KM encouraged her students to collaborate with others and seek help and involve other students in their projects. Arguments and debates among students and instances of students investigating other students' questions were observed only in three classrooms (LS, AR, and KM). Collaborative efforts were encouraged in KM's and AR's classrooms. Six teachers utilized teamwork in their classrooms (HM, AR, OZ, KM, QF, and MN).

\section{Theme 11: Teachers Perceived that the Curriculum and National Test Policies have led them to Focus on Content Delivery rather than Teaching based on their Beliefs}

The Curriculum. The teachers' perceptions of the curriculum highlighted some of the challenges they have been facing in attempting to implement it as planned. First, some of the teachers (WL, KM, OZ, AR, MK, and MM) asserted that it did not help them to implement student-centered learning. OZ and QF thought that the curriculum was designed to be presented and explained by the teacher because the curriculum does not meet students' needs and does not provide students with opportunities to engage in inquiry and research. AR said the learning environment and lack of resources hindered the implementation of studentcentered learning.

OZ: "The curriculum for grade 12 needs to be changed because it is old now and does not enrich students' knowledge and does not meet their needs. The curriculum does not focus on student-centered learning. It is designed to be explained by the teacher and does not give any opportunity for the students to do research"

Second, the majority of the teachers (WL, AR, RH, MK, KM, HM, QF, OZ, $\mathrm{LS}, \mathrm{ZS}, \mathrm{MM}$, and MN) agreed that the curriculum is superficial, lacks depth in its coverage of $\mathrm{CK}$, is vague and unclear, is inconsistent, and fails to provide complete knowledge. They claimed that the content is dense, and that the 
curriculum emphasizes the quantity of topics rather than quality and depth of knowledge. Third, many teachers (WL, AR, MN, OZ, ZS, LS, RH, and KM) complained about the inconsistency of the curriculum content in terms of the misalignment between learning outcomes and the textbook content. Fourth, the teachers claimed that some of the experiments in the textbook are not applicable and indicated they often try to substitute them with others or simply teach them theoretically. Finally, the teachers pointed out that the curriculum has not changed since it was developed in 2008, although it contains many scientific errors. Teachers suggested that the curriculum needs to be reformed to meet students' needs and interests. Teachers described their perceptions of the curriculum, saying:

KM: "It needs to be supplied and enriched with so much information that is missing in the curriculum. It is superficial, but the learning outcomes are detailed and deep. The curriculum is not compatible with the outcomes.... Some of the experiments are not applicable, but we look for alternatives from the internet for better experiments. I change them if possible, but if not possible, I just teach them theoretically"

HM: "It is very dense, and the content is too much. The curriculum is so shallow no depth, so I have to enrich it. I am nearly adding as much as half of the content. I need to cover it in depth. There are too many topics but superficial"

The teachers indicated that they have to comply with the curriculum in terms of the content due to the strict guidelines issued by the Ministry that prohibit any changes to the curriculum. In addition, the final test is on the curriculum's particular content. Below are some excerpts from our interviews with the teachers:

AR: "No we can't omit any topic we should implement the curriculum as it is designed because the test is on the textbook's content. But we can add and enrich it or ask students to do research by themselves"

LS: "We are required to deliver the curriculum exactly as it is planned for, but I change the order of the topics based on students' needs"

The National Test. All the teachers confirmed that the national testing policy has a negative impact on students' learning. The students' goal and focus are on earning high test scores rather than understanding and applying knowledge. Teacher WL said that "it is normal that the students work to get high grades, but in grade 12 it has become an obsession." Furthermore, RH, AR and KM said that their students think about the test almost all the time. KM said that she would focus more on addressing students' interests and learning preferences and making learning more meaningful and interesting if the testing policy were changed.

"If national test policy is changed, I will focus more on taking into consideration students' interests and preferences on what they like to learn. The curriculum would not be so rigid then and we just have to comply and 
teach it as it is. If we have more freedom, learning would be more interesting and meaningful to students"

The impact of the national testing policy on teachers' practices was apparent in the classes observed. The teachers talked about the test and explicitly used test questions and explained how to answer them in all classes observed. They devoted a good portion of the lesson time to preparing students to solve test problems and avoid common mistakes. The students were similarly invested in learning for the test and were very overwhelmed with trying to master the best ways to answer test questions. This contributed to the focus on individual learning instead of cooperative learning. Teachers and students focused on solving problems individually.

\section{Discussion and Assertions}

This study focused on the reform-oriented grade 12 biology curriculum in Oman. The new biology curriculum emphasizes constructivism and encourages student-centered instruction, inquiry-based learning, cooperative learning, problem-solving, and critical thinking. However, since its implementation in 2008, teachers have reported some challenges stemming from the mismatch between the planned curriculum and the implemented curriculum. Consequently, the purpose of this study was to understand how teachers' pedagogical beliefs have shaped their implementation of the reform-oriented science curriculum. The study also sought to identify how biology teachers perceive the relationship between their PCK and their decisions about their instructional approaches.

This study employed an ethnographic approach to data analysis. Multiple data sources were used to generate rich, in-depth data including classroom observations, learning artifacts, reflections, and semi-structured interviews. Three assertions emerged from this study in response to the primary research question: How have biology teachers' pedagogical beliefs shaped the implementation of the reformoriented curriculum in Muscat, Oman? A discussion of the assertions with supporting evidence from the literature and study data follows.

Assertion 1: Teachers' pedagogical beliefs have shaped the implementation of the reform-oriented curriculum by influencing the teachers' conceptualization of the curriculum, their identification of misconceptions, their decisions about classroom teaching practices, and the level of their students' engagement.

Teachers' conceptualizations of the curriculum and student-centered learning were situated within their wider belief systems concerning pedagogy. Consequently, there was a lack of agreement among teachers on the conceptualization of the curriculum in general and the student-centered curriculum and active learning in particular. Teachers' pedagogical beliefs also informed their definitions of the curriculum. The teachers' definitions of active learning reflect a similar lack of agreement. Some teachers (e.g., WL) with significant experience in teaching considered themselves to be implementing active learning when they asked a few students to solve problems on the board. On the other hand, teachers (e.g., AR and 
HM) who had the opportunity to participate in professional development programs that addressed active learning were more specific when they discussed the expected roles of the teacher and students in active learning.

The literature shows a lack of agreement among researchers about the definition of the curriculum in general. The definition is influenced by the perspective of policymakers and practitioners on the one hand and by the purpose the curriculum serves on the other hand. Hence, it is imperative that reform policies and in particular the reform-oriented curriculum adopt an agreed-upon definition for the curriculum, the student-centered curriculum, student-centered learning, and active learning. These definitions should be made public to help guide practice.

Although most of the teachers were able to anticipate their students' misconceptions when learning a new concept based on their experiences, the strategies used to address these misconceptions were influenced by the teachers' beliefs. Teachers who held beliefs that aligned with perennialism and/or essentialism addressed the alternative concepts using strategies such as explaining and asking questions. On the other hand, teachers who held beliefs that aligned with reconstructionism and/or progressivism used strategies such as confronting, problem-solving, teamwork, and research. These findings are in alignment with Hashweh's (1996) findings that constructivist teachers are better prepared than empiricist teachers are to induce student conceptual change. Hashweh (1996) said this was because the constructivist teachers perceive scientific knowledge development as a process of conceptual change; hence, they utilize effective strategies to confront alternative misconceptions and facilitate cognitive restructuring. Teachers with beliefs that aligned with progressivism and reconstructionism focused on cognitive depth, hands-on activities, inquiry-based learning, and cooperative learning to enhance student learning. They employed formative assessments to adjust their teaching. They actively engaged students in discussions and problem-solving. Furthermore, they employed different teaching strategies in the lessons observed. However, teachers who held mixed sets of beliefs or beliefs that aligned with essentialism or perennialism tended to rely on discussion and problem-solving. These findings correspond with other studies' (e.g., Levitt, 2001; Wallace \& Priestley, 2011; 2017) findings that when teachers' beliefs resonate with the philosophy of a reform, they enthusiastically promote the reform. This study's findings are also in line with those of Feldman (2002) and Cronin-Jones (1991), both of whom found that teachers' practices are compatible with a reform-oriented constructivist curriculum if their beliefs are well aligned with the curriculum.

Teachers with constructivist beliefs encouraged the active engagement of students by asking them to provide evidence supporting their responses or to identify alternative ways to solve problems. They emphasized students' interaction with other students through debates, arguments, and investigations of other students' questions. Van Uden, Ritzen, and Pieters (2014) pointed out that teachers' beliefs should be consistent with their actions in the classroom; hence, these beliefs should ultimately impact student engagement.

Assertion 2: Teachers believe that it is their role to develop their PCK to be 
able to implement reform-oriented instruction.

The participating biology teachers indicated that they sought to develop their PCK through interactions with students, mentors, and colleagues. Opportunities to learn from peers and supervisors also shaped and developed the teachers' PCK. Additionally, the teachers indicated that engagement and experiences with reformoriented curriculum implementation encouraged them to research and learn about inquiry-based learning, student-centered learning, and active learning.

These findings correspond with those of previous research. Some studies have reported that new science teachers develop their PCK as they interact with students (Luft, Firestone, Wong, Ortega, Adams, \& Bang, 2011), mentors (Simonsen, Luebeck, \& Bice, 2009), colleagues, and curricular materials (Schneider \& Krajcik, 2002). Our findings challenge Rozenszajn and Yarden's (2014b) assertion that biology teachers neglect the need to update their PCK while investing time and energy in keeping up-to-date with developments in biological CK. The biology teachers in our study tended to focus on developing their PCK, probably because they realized their lack of PCK was insufficient to implement the reformoriented curriculum. In addition, they saw that their preparation in college had not prepared them for a student-centered learning environment.

Interestingly, all teachers indicated they lacked PCK regardless of the type of qualification they held. Ten teachers had a Baccalaureate of Education and four had a Baccalaureate of Science (major biology) and one-year Diploma of Education. The results show that beliefs had more influence on teachers' instructional practices than their level of CK or PCK. This finding aligns with Mewborn (2001) and Wilkins (2008) assertion that teachers beliefs shape their instruction more than their level of CK and PCK. However, teachers with progressivist and reconstructionist beliefs strove to improve their PCK so that they would be prepared to teach the reform-oriented curriculum.

Moreover, the study findings suggest that there is room to improve teachers' implementation of the reform-oriented curriculum and instruction by designing specific professional development programs to influence the teachers' beliefs and hence practices. Moreover, teachers' practices can be strengthened by continuing to focus on the teachers' self-directed learning and learning from peers and by linking this learning to improved professional learning communities (PLCs).

Assertion 3: Reform-oriented curriculum implementation procedures contribute to a lack of congruence between teachers' pedagogical beliefs and practice.

The phenomenon of science teachers holding positive beliefs related to reform-oriented teaching but facing challenges in enacting these practices in school cultures of accountability has been documented as a significant barrier to adopting innovative practices (Wallace, 2014). The biology teachers expressed tacit beliefs that were more in accordance with the constructivist perspective and student-centered approach to learning. However, they indicated that national test and curriculum implementation procedures had hindered them from teaching in alignment with their beliefs. The majority of the teachers believed that the curriculum did not stress student-centered learning because it focused on $\mathrm{CK}$ and lacked opportunities for students to practice research, active learning, and inquiry- 
based learning. All teachers remarked that because of the test, they spend less time on inquiry-based learning and research than they do on teaching to the test.

\section{Conclusion}

The limitation of this study is related to the purposeful sampling of participants rather than random selection. School and teacher selection criteria based on students' achievement needed to be adjusted to ensure the inclusion of both all-boys' and all-girls' schools, as well as schools of varying achievement levels and from different states in Muscat. Hence, the findings of this study may have limited generalizability.

The results of this study emphasize the complex relationship between beliefs and PCK, which highlights the need for professional development programs for newly hired science teachers and in-service teachers to sustain and strengthen their beliefs and PCK. Such programs should promote pedagogical beliefs and knowledge related to student-centered learning and focus on relevant classroom practices so that the enacted science instructional practices promote students' learning. Moreover, teacher-education programs need to place greater emphasis on developing science teachers' beliefs and PCK. Future research might investigate how teachers' beliefs develop and change with experience and which aspects of professional development programs lead to changes in teachers' beliefs. Additional research on the beliefs of teacher-educators and how these beliefs shape their instruction is critical to understand the influence of teacher- educators' beliefs and practices on teacher-candidates' beliefs.

\section{References}

Al-Balushi, S., \& Al-Rawahi, N. (2011). Investigating Omani physical education and science teachers' beliefs in cooperative learning using the theory of planned behavior. The Educational Journal (Kuwait University), 26(101-part One), 285-322.

Al Balushi, S., \& Griffiths, D. (2013). The school education system in the Sultanate of Oman. In Education in the broader Middle East: Borrowing a baroque arsenal, G. Donn, \& Y. Al Manthri. Oxford: Symposium books Ltd.

Al-Harthi, A. (2008). The relationship between science teacher's beliefs about the use of inquiry-based learning strategy and their classroom practices (Unpublished Master Thesis). Sultan Qaboos University, Sultanate of Oman.

Ambusaidi, A., \& Al-Balushi, S. (2015). Science education in the Sultanate of Oman. In Science education in the Arab Gulf States: Visions, sociocultural contexts and challenges, N. Mansour, \& S. Al-Shamrani. Sense Publishers.

Ambusaidi, A., \& Al-Balushi, S. (2012). A longitudinal study to identify prospective science teachers' beliefs about science teaching using the draw-a-science-teachertest-checklist. International Journal of Environmental \& Science Education, 7(2), 291-311.

Badiali, B. (2005). Standards for supervision of curriculum development. In Standards for instructional supervision, enhancing teaching and learning, S. Gordon (ed.). Larchmont, NY: Eye on Education. 
Bektas, O., \& Taber, K. (2009). Can science pedagogy in English schools inform educational reform in Turkey? Journal of Turkish Science Education, 16(3), 66-80.

Bogdan, R.C., \& Biklen, S.K. (2007). Qualitative research for education: Introducing theories and methods, (5 $5^{\text {th }}$ ed.). Boston: Pearson.

Borko, H., Stecher, B., \& Kuffner, K. (2007). Using artifacts to characterize reformoriented instruction: The scoop notebook and rating guide. CSE technical report 707. National Center for Research on Evaluation, Standards, and Student Testing (CRESST).

Brandon, A., \& All, A. (2010). Constructivism theory analysis and application to curricula. Nursing Education Perspectives, 31(2), 89-92.

Braun, V., \& Clarke, V. (2006). Using thematic analysis in psychology. Qualitative Research in Psychology, 3, 77-101.

Carlsen, S. (1987). Why do you ask? The effects of science teacher subject-matter knowledge on teacher questioning and classroom discourse. Paper presented at the Annual Meeting of the American Educational Research Association. (ERIC Document Reproduction Service NO. ED 293 181).

Cochran, K., King, A., \& DeRuiter, A. (1991). Pedagogical content knowledge: An integrative model for teacher preparation. Journal of Teacher Education, 44(4), 263272.

Creswell, J., \& Plano Clark, V. (2011). Designing and conducting mixed methods research $\left(2^{\text {nd }}\right.$ ed.). Thousand Oaks: Sage.

Cronin-Jones, J. (1991). Science teacher beliefs and their influence on curriculum implementation: Two case studies. Journal of Research in Science Teaching. 28(3): 235-250.

Deng, F., Chai, C., Tsai, C., \& Lee, M. 2014. The relationships among Chinese practicing teachers' epistemic beliefs, pedagogical beliefs and their beliefs about the use of ICT. International Forum of Educational Technology \& Society, 17(2), 245-256.

Feldman, A. (2002). Multiple perspectives for the study of teaching: Knowledge, understanding and being. Journal of Research in Science Teaching, 39, 1032-1055.

Fives, H., \& Buehl, M. 2012. Spring cleaning for the "messy" construct of teachers' beliefs: What are they? Which have been examined? What can they tell us? In APA Educational Psychology Handbook, K. R. Harris, S. Graham, T. Urdan, S. Graham, J. M. Royer, \& M. Zeidner (Eds.),vol. 2, (pp. 471-499). Washington, DC: American Psychological Association.

Fives, H., \& Buehl, M. (2016). Teachers' beliefs, in the context of policy reform. Policy Insights from the Behavioral and Brain Sciences, 3(1), 114-121.

Fosnot, C. (1996). Constructivism: A psychological theory of learning. In Constructivism: Theory, Perspectives and Practice, C. T. Fosnot (ed.), (pp. 8-33). New York: Teachers College Press.

Grossman, L. (1990). The making of a teacher: Teacher knowledge and teacher education. New York: Teachers College Press.

Haney, J., Lumpe, A., \& Czerniak, C. (2003). Constructivist beliefs about the science classroom learning environment: Perspective from teachers, administrators, parents, community members, and students. School Science and Mathematics, 103(8), 366377.

Hashweh, M. (1996). Effects of science teachers' epistemological beliefs in teaching. Journal of Research in Science Teaching, 33(1), 47-63.

Issan, S., \& Gomaa, N. (2010). Post basic education reform in Oman: A case study. Literacy Information and Computer Education Journal, 1(1), 19-27. 
Jones, G., \& Carter, G. (2007). Science teacher attitudes and beliefs. In Handbook of Research on Science Education, S.K. Abell \& N.G. Lederman (eds.), (pp. 10671104). Mahwah, New Jersey: Lawrence Erlbaum Associates.

Kagan, D. (1992). Implications of research on teacher belief. Educational Psychologist, $27(1), 65-90$.

Le, V.N., Lockwood, J., Stecher, B., Hamilton, L., \& Martinez, J. (2009). A longitudinal investigation of the relationship between teachers' self-reports of reform-oriented instruction and mathematics and science achievement. Educational Evaluation and Policy Analysis, 31(3), 200-220.

Levitt, K. (2001). An analysis of elementary teachers' beliefs regarding the teaching and learning of science. Science Education, 86(1), 1-22.

Lincoln, Y., \& Guba, E. (1985). Naturalistic inquiry. Beverly Hills: Sage.

Luft, J., Firestone, J., Wong, S., Ortega, I., Adams, K., \& Bang, E. (2011). Beginning secondary science teacher induction: A two-year, mixed methods study. Journal of Research in Science Teaching, 48(10), 1199-1244.

Lui, A., \& Bonner, S. (2016). Preservice and in-service teachers' knowledge, beliefs, and instructional planning in primary school mathematics. Teaching and Teacher Education, 56, 1-13.

Manno, J.L. (2011). K-5 Mentor teachers' journeys toward reform-oriented science within a professional development school context. The Pennsylvania State University.

Martinez, J., Borko, H., \& Stecher, B. (2012). Measuring instructional practice in science using classroom artifacts: Lessons learned from two validation studies. Journal of Research in Science Teaching, 49(1), 38-67.

Maxwell, J.A. (2013). Qualitative Research Design: An Interactive Approach, $3^{\text {rd }}$ ed. Thousand Oaks, CA: Sage.

Mewborn, D. (2001). Teachers content knowledge, teacher education, and their effects on the preparation of elementary teachers in the United States. Mathematics Teacher Education and Development, 3, 28-36.

Ministry of Education, Oman and the World Bank. (2012). Education in Oman: The drive for quality. MOE, Oman.

National Research Council (NRC). (1996). National science education standards. Washington, DC: National Academy Press.

Pajares, F. (1992). Teachers' beliefs and educational research: Cleaning up a messy construct. Review of Educational Research, 62(3), 307-332.

Park, S., Jang, J., Chen, Y., \& Jung, J. (2011). Is pedagogical content knowledge (PCK) necessary for reformed science teaching?: Evidence from an empirical study. Research Science Education, 41, 250-260.

Park, S., \& Oliver, J. 2008. Revisiting the conceptualization of pedagogical content knowledge (PCK): PCK as a conceptual tool to understand teachers as professionals. Research Science Education, 38, 261-284.

Pedersen, S., \& Liu, M. (2003). Teachers' beliefs about issues in the implementation of a student-centered learning environment. Educational Technology Research and Development, 51(2), 57-76.

Richardson, V. (1990). Significant and worthwhile change in teaching practice. Educational Researcher, 19(7), 10-18.

Roehrig, G., \& Garrow, S. (2007). The impact of teacher classroom practices on student achievement during the implementation of a reform-based chemistry curriculum. International Journal of Science Education, 29(14), 1789-1811.

Rozenszajn, R., \& Yarden, A. (2014a). Expansion of biology teachers' pedagogical content knowledge (PCK) during a long-term professional development program. Research in Science Education, 44(1), 189-213. 
Rozenszajn, R., \& Yarden, A. (2014b). Mathematics and biology teachers' tacit views of the knowledge required for teaching: Varying relationships between CK and PCK. International Journal of STEM Education, 1(11), 1-12.

Sampson, V., Enderle, P., \& Grooms, J. (2013). Development and initial validation of the beliefs about reformed science teaching and learning (BARSTL) questionnaire. School Science and Mathematics, 113(1), 3-15. Retrieved from https://bit.ly/39zRkZg.

Sawada, D., Piburn, M., Judson, E., Truly, J., Falconer, K., Benford, R., \& Bloom, I. (2002). Measuring reform practices in science and mathematics classrooms: The reformed teaching observations protocol. School Science and Mathematics, 10(6), 245- 253.

Schneider, R., \& Krajcik, J. (2002). Supporting Science Teacher Learning: The Role of Educative Curriculum Materials. Journal of Science Teacher Education, 13(3), 221245. doi:10.1023/a:1016569117024.

Shulman, L. (1986). Those who understand: knowledge growth in teaching. Educational Researcher, 15(1), 4-14.

Shulman, L. (1987). Knowledge and teaching: foundations of the new reform. Harvard Educational Review, 57(1), 1-22.

Simonsen, L., Luebeck, J., \& Bice, L. 2009. The effectiveness of online paired mentoring for beginning science and mathematics teachers. Journal of Distance Education, 23(2), 51- 68.

Tondeur, J., van Braak, J., Ertmer, P., \& Ottenbreit-Leftwich, A. (2017). Understanding the relationship between teachers' pedagogical beliefs and technology use in education: A systematic review of qualitative evidence. Education Technology Research Development, 65, 555-575. doi 10.1007/s11423-016-9481-2.

Van Uden, J., Ritzen, H., \& Pieters, J. (2014). Engaging students: The role of teacher beliefs and interpersonal teacher behavior in fostering student engagement in vocational education. Teaching and Teacher Education, 37 (2014), 21-32.

Vygotsky, L. (1986). Thought and language. Cambridge, MA: MIT Press.

Wallace, C. (2014). Overview of the role of teacher beliefs in science education. In The role of science teachers' beliefs in international classrooms, Evans et al. (eds), (pp. 17-31). Sense Publishers.

Wallace, C., \& Priestley, M. 2017. Secondary science teachers as curriculum makers: Mapping and designing Scotland's new curriculum for excellence. Journal of Research in Science Teaching, 54(3), 324-349.

Wallace, C., \& Priestley, M. (2011). Teacher beliefs and the mediation of curriculum in Scotland: A socio-cultural perspective on professional development and change. Journal of Curriculum Studies, 43(3), 357-381.

Wilkins, J. (2008). The relationship among elementary teachers' content knowledge, attitudes, beliefs, and practices. Journal of Mathematics Teacher Education, 11(2), 139-164.

Yager, S., Akcay, H., Dogan, O., \& Yager, R. (2013). Student views of teacher actions in science classrooms designed to meet current reforms. Journal Science Education Technology, 22(6), 974-983.

Yildirim, A., \& Kasapoglu, K. (2015). Teachers' perceptions of constructivist curriculum change as a predictor of their perceptions of the implementation of constructivist teaching-learning activities. Asia Pacific Education Review, 16(4), 565-577. 


\section{Appendix (A)}

\section{Reform-Oriented Classroom Observation Protocol}

Researcher:

Teacher:

School/State:

Topic of lesson:

Day and Date:

Instruments employed, and data collected:

Classroom observation protocol

Teacher's pre-observation feedback

Teacher's post-observation feedback

Teaching and learning artifacts (lesson plan-assessments-quizzes-final testsresearch-projects-homework-classroom activities-students notes and notebooks-worksheets)

\begin{tabular}{|c|c|c|c|c|c|}
\hline \multirow{2}{*}{ Domain } & \multirow{2}{*}{ Items } & \multirow{2}{*}{ Indicators } & \multicolumn{3}{|c|}{$\begin{array}{l}\text { Usage of Reform } \\
\text { Practices* }\end{array}$} \\
\hline & & & $\begin{array}{c}\text { Never } \\
\text { used }\end{array}$ & $\begin{array}{l}\text { Average } \\
\text { use }\end{array}$ & $\begin{array}{l}\text { Highly } \\
\text { used }\end{array}$ \\
\hline \multirow{9}{*}{$\begin{array}{l}\text { D1: Planning } \\
\text { and Lesson } \\
\text { Design }\end{array}$} & \multirow{2}{*}{ Entry } & $\begin{array}{c}\text { Students prior } \\
\text { knowledge }\end{array}$ & & & \\
\hline & & $\begin{array}{l}\text { Students questions/ } \\
\text { ideas }\end{array}$ & & & \\
\hline & \multirow{5}{*}{ Lesson Structure } & Conceptually coherent & & & \\
\hline & & $\begin{array}{c}\text { Logical sequence of } \\
\text { tasks }\end{array}$ & & & \\
\hline & & $\begin{array}{l}\text { Student engagement in } \\
\text { inquiry/experimentation }\end{array}$ & & & \\
\hline & & $\begin{array}{l}\text { Student exploration } \\
\text { precedes formal } \\
\text { presentation }\end{array}$ & & & \\
\hline & & $\begin{array}{l}\text { Activities based on } \\
\text { relevant real-world } \\
\text { phenomena and } \\
\text { scientific ideas }\end{array}$ & & & \\
\hline & Lesson Elements & $\begin{array}{l}\text { Focus on important } \\
\text { problems, issues, or } \\
\text { questions about } \\
\text { phenomena }\end{array}$ & & & \\
\hline & Closure & $\begin{array}{c}\text { Conclusions or } \\
\text { generalization from } \\
\text { evidence }\end{array}$ & & & \\
\hline \multirow{6}{*}{$\begin{array}{l}\text { D2: } \\
\text { Instructional } \\
\text { Practices }\end{array}$} & \multirow{6}{*}{ Grouping } & $\begin{array}{l}\text { Heterogeneous } \\
\text { configurations }\end{array}$ & & & \\
\hline & & Work in pairs & & & \\
\hline & & Groups of 3-5 students & & & \\
\hline & & $\begin{array}{c}\text { Groups of more than } 5 \\
\text { students }\end{array}$ & & & \\
\hline & & $\begin{array}{l}\text { Group work for less than } \\
10 \text { minutes }\end{array}$ & & & \\
\hline & & $\begin{array}{l}\text { Group work for more } \\
\text { than } 10 \text { minutes }\end{array}$ & & & \\
\hline
\end{tabular}




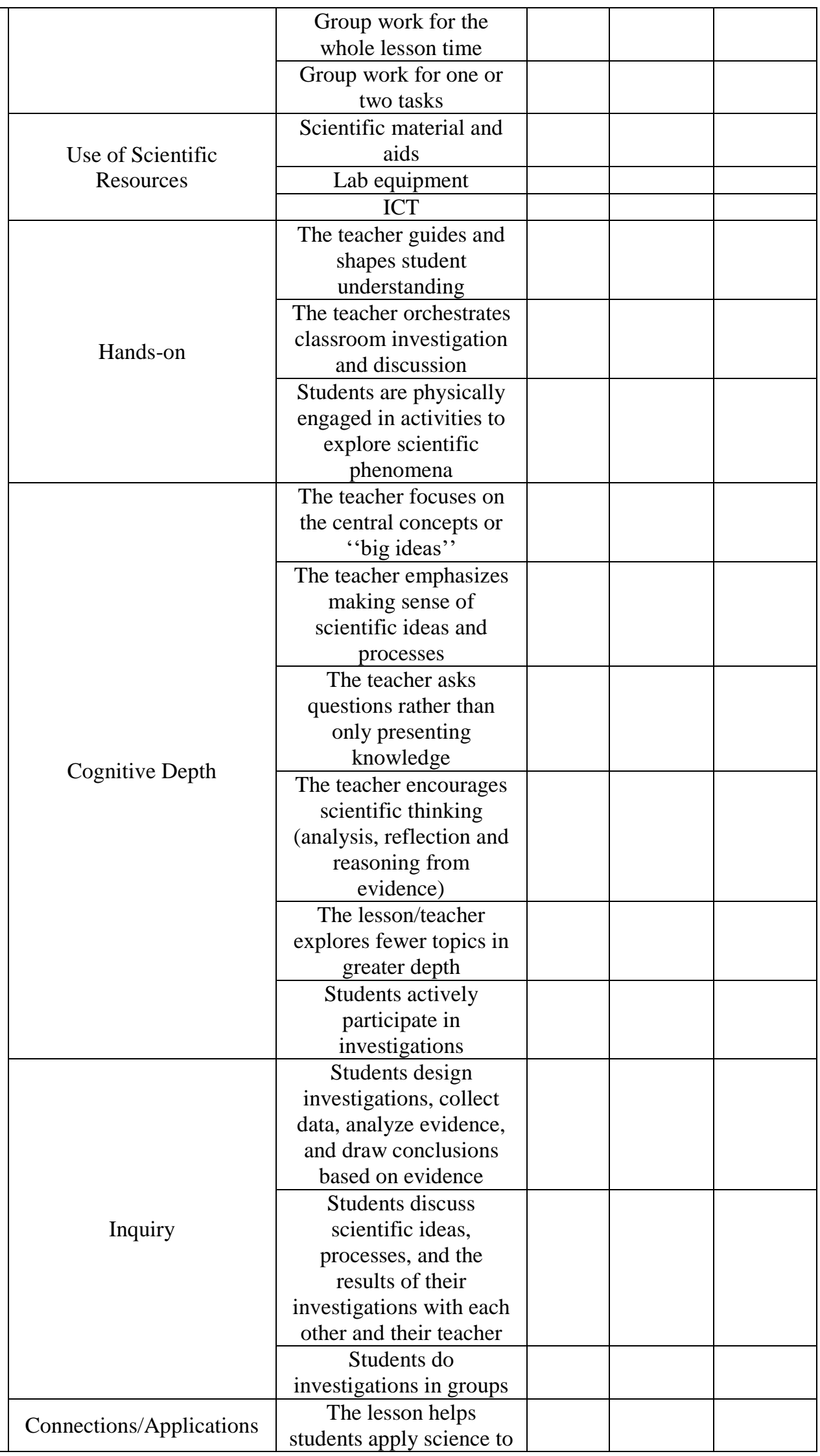




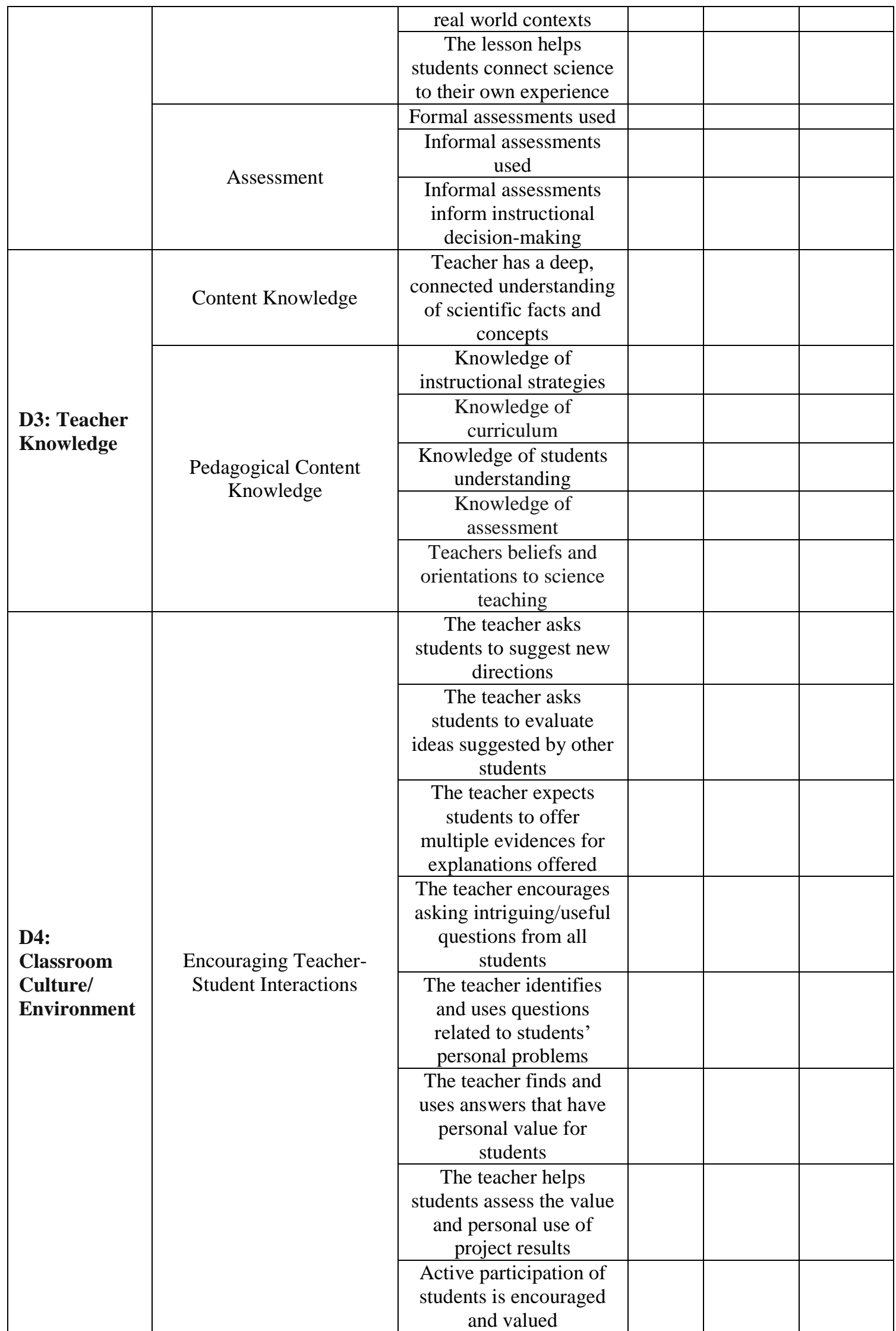




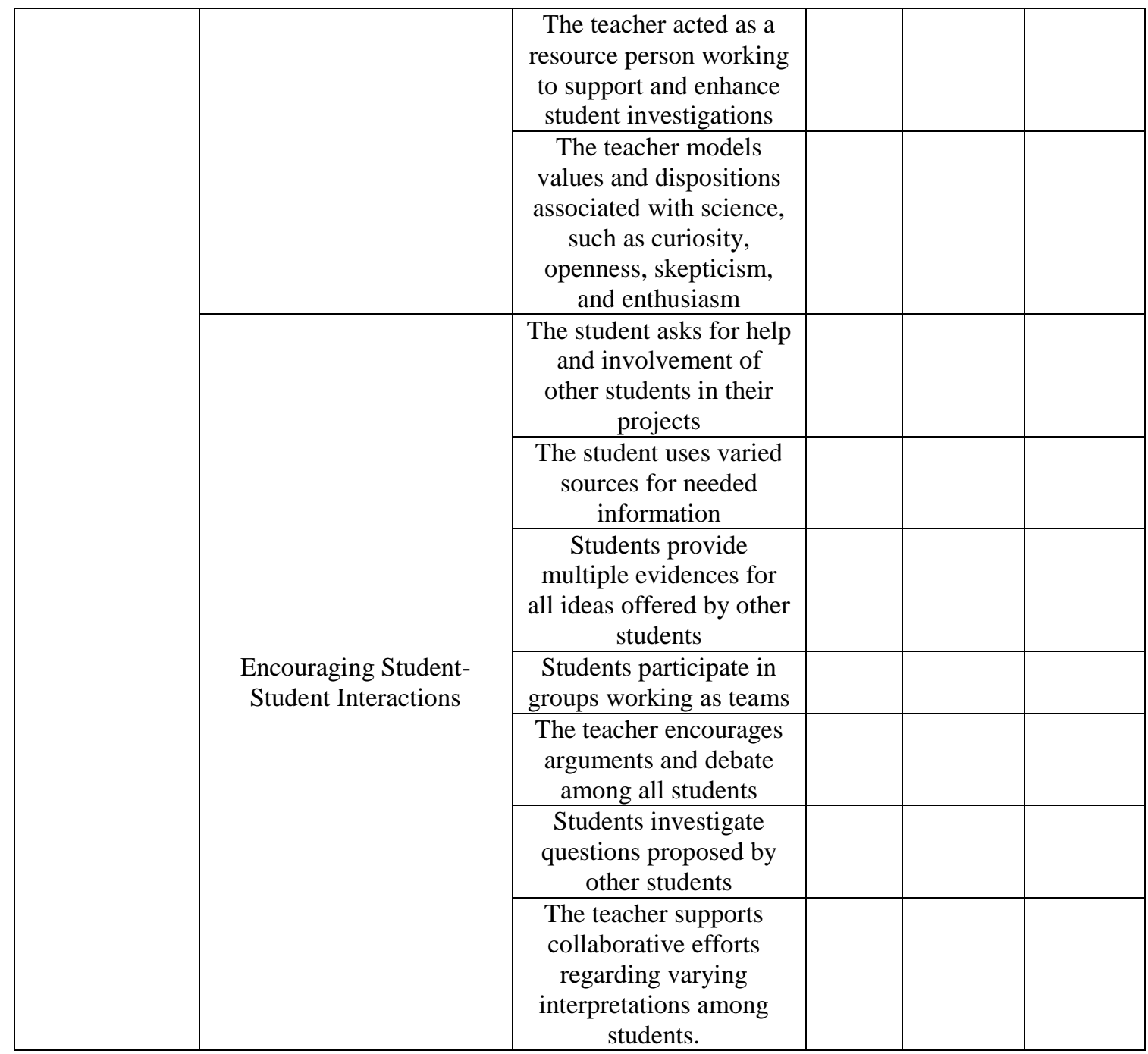

$*$ Never used $=0$ times used. Average use $=2-4$ times or $20-50 \%$ of the lesson time. Highly used $=$ more than 4 times or more than $50 \%$ of the lesson time.

\section{D1: Planning and Lesson Design}

- Entry: The Lesson begins with provocative thoughts, e.g., students' questions or observations, and provides for experimentation or other means of gathering information, rather than being organized around exposition and recall of material. The instructional strategies and activities respect students' prior knowledge and the preconceptions inherent therein. The lesson is planned to address student ideas and prerequisite ideas needed for understanding, rather than just covering the topic. The lesson is designed to engage students as members of a learning community.

- Lesson structure: The lesson is organized in ways that promote scientific understanding. The lesson is conceptually coherent, and the activities are organized to build upon on one another in a logical manner. The teacher involves the students in a sequence of tasks to shape students' scientific thinking and sense-making about the question under study (explaining, predicting, describing, analyzing), rather than in just a set of assignments related to a topic but not structured to foster scientific understanding. Student exploration planned to precede formal presentation. The teacher identifies relevant real-world phenomena and representations of scientific ideas that match with learning goals and students' ideas and experiences, to 
develop a logical sequence of instructional activities, rather than just selecting interesting activities connected to the general topic of study without attention to specific content.

- Lesson elements: The Lesson includes effective elements to achieve the goal of scientific understanding. Topic/Lesson begins with a focus on important problems, issues, or questions about phenomena that are interesting or familiar to students, rather than topics chosen for unknown reasons.

- Closure: Lessons culminate in conclusions or generalization from evidence, rather than just finishing an activity or a period of time.

\section{D2: Instructional Practices}

- Grouping: The extent to which the teacher enables students to work together in groups to complete scientific tasks. The teacher organizes students in a variety of configurations to promote social interaction and collaboration as required by the task at hand (e.g., partners for lab experiments, discussions, or presentations by groups of four); they do not confine instruction to whole-class or individual modes.

- Use of Scientific Resources: The extent to which a variety of resources (e.g., ICT, laboratory equipment, and scientific tools) are utilized. Appropriate materials are available and are used. Instructional materials emphasize key science concepts, take into account likely student knowledge about the content being addressed and provide opportunities to confront and reconsider misconceptions. The Teacher has access to wide variety of general instructional materials and consumable supplies, so instruction does not have to rely solely on textbooks and worksheets.

- Hands-On: The extent to which students are physically engaged in activities to explore scientific phenomena by handling materials and scientific equipment. The role of the teacher includes orchestrating classroom investigation and discussion, so students' ideas are central, rather than always being the authority who presents knowledge. The teacher guides and shapes student understanding by providing knowledge at the right moment when the student needs to know it to complete a task.

- Inquiry: The extent to which the lesson allows the students to actively participate by asking scientific questions, design investigations, collect data, analyze evidence, and draw conclusions based on evidence. Students should be engaged in activities that support the development of scientific understanding like taking an active role in their education by formulating questions, collecting information, and synthesizing results, rather than merely reading about or listening to explanations of science. Students discuss scientific ideas, processes, and the results of their investigations with each other and their teacher (learning how to reason from evidence, connect ideas to those of others, challenge ideas, etc.), rather than just reciting facts previously learned from the teacher or textbook. Students understand why they are doing each activity and how it links with target concept being taught, rather than completing activities as given with no sense of connection. The teacher asks students to participate in scientific exploration in groups, using real materials rather than just explaining facts and describing procedures.

- Cognitive Depth: The teacher focuses on the central concepts or "big ideas", connections, and relationships among science concepts. The teacher emphasizes making sense of scientific ideas and processes and extracting concepts from what has occurred, rather than just learning facts and procedures. The teacher asks questions that will help students focus on and come to understand science concepts and the connections among them, rather than only presenting knowledge. The teacher supports scientific habits of mind by encouraging scientific thinking 
(analysis, reflection), rather than accepting knowledge without question. The teacher encourages reasoning from evidence and focus on "how we know" scientific concepts, rather than accepting knowledge without justification. The lesson/teacher explores fewer topics in greater depth to encourage understanding, as opposed to providing limited exposure to a wide variety of topics. The teacher motivates students to be engaged and to participate actively in science learning, rather than being passive or uninterested.

- Assessment: The extent to which the lesson includes a variety of formal and informal assessment strategies that measure student understanding. They are used to inform instructional decision-making for gauging students' learning, rather than merely evaluating students' achievement at the end of instruction.

- Connections/Applications: The extent to which the lesson helps students connect science to their own experience, apply science to real world contexts, or understand the role of science in society. The teacher focuses on relevance of knowledge by connecting science to students' own experiences and perceptions of the natural world, rather than presenting it in isolation.

\section{D3: Teacher Knowledge}

- Content knowledge: Teacher has a deep, connected understanding of scientific facts and concepts and the ways in which they are used in the real world.

- Pedagogical content knowledge: Teacher has extensive knowledge of strategies for communicating information and developing conceptual understanding in alternative ways. Following Park and Oliver (2008), PCK refers to (a) teachers' beliefs and orientations to science teaching, (b) knowledge of students' understanding in science, (c) knowledge of science curriculum, (d) knowledge of instructional strategies and representations for teaching science, and (e) knowledge of assessments of science learning.

\section{D4: Classroom Environment/Culture}

- Encouraging Teacher-Student Interactions: The teacher asks students to help with suggesting new directions and evaluates ideas suggested by other students. The teacher expects students to offer multiple evidences for explanations offered. The teacher encourages asking intriguing/useful questions from all students and identifies and uses questions related to personal problems. The teacher finds and uses answers that have personal value for students and encourages use of science class experiences in the daily lives of students. The teacher helps students assess the value and personal use of project results. Active participation of students is encouraged and valued. Students are encouraged to generate conjectures, alternative solution strategies, and ways of interpreting evidence. In general, the teacher is patient with students. The teacher acted as a resource person working to support and enhance student investigations. The metaphor "teacher as listener" is very characteristics of this classroom. The teacher models values and dispositions associated with science, such as curiosity, openness, skepticism, and enthusiasm, rather than fostering a reliance on authority and established sources of information.

- Encouraging Student-Student Interactions: The student asks for help and involvement of other students in their projects. The student uses varied sources for needed information and tries new ideas and explanations for use in whole class discussions. Students provide multiple evidences for all ideas offered by other students. Students participate in groups working as teams. The teacher encourages arguments and debate among all students. Students investigate questions proposed by other students and share ideas and interpretations with others in the school and 
community. The teacher supports collaborative efforts regarding varying interpretations among students.

\section{Appendix (B)}

\section{Teacher's Pre-Observation Reflection Form}

1. Could you briefly describe today's lesson?

2. What kinds of things did you take into consideration in planning this lesson?

3. What concepts in this topic do you believe are the most important for your students to understand by the end of the instruction of this topic? Why?

4. What content or concepts do you expect students would have difficulties with today? Why do you think so?

5. Reflecting on your experience of teaching this topic, what kinds of student misconceptions associated with this unit/topic have you noticed?

6. How do you challenge the misconceptions/How would you help them correct the misconceptions?

7. What evidence are you looking for that students have been successful in addressing the goals and understand the concepts you try to teach today?

\section{Appendix (C) \\ Teacher's Post-Observation Reflection Form}

1. How do you feel about the lesson today?

2. What do you consider the most effective teaching moment was in the lesson? Why? How did you achieve it? Why did it work?

3. What signaled you that students were learning?

4. Were there any student misconceptions you identified during the class that you haven't known? If yes, how did you respond to challenge the misconceptions? Did it work? Why do you think it worked?

5. Did you make any changes in the class that I just observed differently from the other class periods or lesson plan? Why?

\section{Appendix (D) \\ Personal Curriculum Q-Sort (Adapted from Badiali, 2005)}

Below you will find 20 statements that characterize our public system of education. These statements are arranged in four categories; they address 1) the aims of education; 2) the nature of knowledge; 3) the role of the teacher; and 4) the purpose of the curriculum. These are foundational considerations for curriculum. Your task is to prioritize these statements by numbering them one to five in each category. Assign the number 5 to the statement you believe best represent your beliefs, 4 to the statement you believe represents your beliefs next best, and so on until you have numbered all 5 statements in each section. At the end of the Q-sort there is a scoring rubric.
Aims of Education
A. --- To improve and reconstruct society; education for change
B. --- To promote democratic, social living, to foster creative self-learning 
C. --- To educate the rational person; to cultivate the intellect through transmitting worthwhile knowledge that has been gathered, organized, and systematized

D. --- To provide for the construction of active citizens; to nourish civic literacy, citizen participation, and political responsibility

E. --- To promote the intellectual growth of the individual; to educate the competent person for the benefit of humanity

\section{Nature of Knowledge}

A. --- Focus on skills and subjects needed to identify and ameliorate problems of society; active concern with contemporary and future society

B. --- Focus on past and permanent studies, mastery of facts and universal truths

C. --- Focus on reconstructing a visionary language and public philosophy that puts equality, liberty, and human life at the center of the notions of democracy and citizenship

D. --- Focus on growth and development; a living-learning process; active and relevant learning

E. --- Focus on essential skills and academic subjects; mastery of concepts and principles of subject matter

\section{Role of the Teacher}

A. --- Teachers are critical intellectuals who create democratic sites for social transformation. They empower students to question how knowledge is produced and distributed

B. --- Teachers serve as change agents for reform; they help students become aware of problems confronting humanity

C. --- Teachers should help students think rationally; teach based on Socratic method, oral exposition, relaying explicit traditional values

D. --- Teachers are guides for problem solving and scientific inquiry

E. --- teachers should act as authority figures who have expertise in subject areas

\section{Curriculum purposes}

A. --- Curriculum centers on classical subjects, literacy analysis. It is constant

B. --- Curriculum centers on social critique and social change dedicated to self and social-empowerment

C. --- Curriculum centers around essential skills in the 3 R's (readin', 'ritin', 'rithmetic) and major content areas (English, science, math, history, foreign language)

D. --- Curriculum centers on examining social, economic, and political problems, from present/ future, national/international perspectives

E. --- Curriculum centers on student interests; involves the application of human problems; subject matter is interdisciplinary 


\section{Scoring guide for curriculum philosophy Q-sort (Badiali, 2005)}

When you have completed the Q-sort exercise, go back and look at each category. Place the number that you assigned to each statement in the space provided in the following rubric. Add the columns to determine the educational/curricular philosophy with which you most agree. Grouped together, these statements represent major tenets of five educational/curricular philosophies.

\begin{tabular}{|c|c|c|c|c|c|}
\hline & Perennialism & Essentialism & Progressivism & $\begin{array}{c}\text { Social } \\
\text { Reconstructionism }\end{array}$ & $\begin{array}{c}\text { Critical } \\
\text { Theory }\end{array}$ \\
\hline Aims & C & E & B & A & D \\
\hline Knowledge & B & E & D & A & C \\
\hline $\begin{array}{c}\text { Teacher's } \\
\text { Role }\end{array}$ & C & E & D & B & A \\
\hline $\begin{array}{c}\text { Curriculum } \\
\text { Totals }\end{array}$ & A & C & E & D & B \\
\hline
\end{tabular}

The taxonomy below is adapted from Badiali (2005)

\begin{tabular}{|c|c|c|c|c|c|c|}
\hline & $\begin{array}{c}\text { Philosophical } \\
\text { Base }\end{array}$ & $\begin{array}{l}\text { Instructional } \\
\text { Objectives }\end{array}$ & Knowledge & $\begin{array}{l}\text { Role of } \\
\text { Teacher }\end{array}$ & $\begin{array}{l}\text { Curriculum } \\
\text { Focus Trends }\end{array}$ & $\begin{array}{c}\text { Related } \\
\text { Curriculum }\end{array}$ \\
\hline Perennialism & Realism & $\begin{array}{l}\text { To educate } \\
\text { the rational } \\
\text { person; to } \\
\text { cultivate } \\
\text { intellect }\end{array}$ & $\begin{array}{l}\text { Focus on past } \\
\& \text { permanent } \\
\text { studies; } \\
\text { mastery of } \\
\text { facts and } \\
\text { timeless } \\
\text { knowledge }\end{array}$ & $\begin{array}{c}\text { Teacher } \\
\text { helps } \\
\text { students } \\
\text { think } \\
\text { rationally; } \\
\text { based on } \\
\text { the Socratic } \\
\text { method and } \\
\text { oral } \\
\text { exposition; } \\
\text { explicit } \\
\text { teaching of } \\
\text { traditional } \\
\text { values }\end{array}$ & $\begin{array}{c}\text { Classical } \\
\text { subject; literary } \\
\text { analysis; } \\
\text { constant } \\
\text { curriculum }\end{array}$ & $\begin{array}{l}\text { Great books } \\
\text { Paideia } \\
\text { proposal } \\
\text { (Hutchins, } \\
\text { Adler) }\end{array}$ \\
\hline Essentialism & $\begin{array}{l}\text { Idealism; } \\
\text { Realism }\end{array}$ & $\begin{array}{l}\text { To promote } \\
\text { the } \\
\text { intellectual } \\
\text { growth of the } \\
\text { individual; to } \\
\text { educate the } \\
\text { competent } \\
\text { person }\end{array}$ & $\begin{array}{c}\text { Essential } \\
\text { skills and } \\
\text { academic } \\
\text { subjects; } \\
\text { mastery of } \\
\text { concepts and } \\
\text { principles of } \\
\text { subject matter }\end{array}$ & $\begin{array}{l}\text { Teacher is } \\
\text { authority in } \\
\text { his or her } \\
\text { field; } \\
\text { explicit } \\
\text { teaching of } \\
\text { traditional } \\
\text { values }\end{array}$ & $\begin{array}{l}\text { Essential skills } \\
\text { (the three r's) } \\
\text { and essential } \\
\text { subjects (Eng, } \\
\text { math, science, } \\
\text { history, for. } \\
\text { language) }\end{array}$ & $\begin{array}{c}\text { Back to } \\
\text { basics; } \\
\text { excellence in } \\
\text { education } \\
\text { (Bagley, } \\
\text { Bestor, } \\
\text { Bennett) }\end{array}$ \\
\hline Progressivism & Pragmatism & $\begin{array}{l}\text { To promote } \\
\text { democratic, } \\
\text { social living }\end{array}$ & $\begin{array}{l}\text { Knowledge } \\
\text { lends to } \\
\text { growth and } \\
\text { development; } \\
\text { a living- } \\
\text { learning } \\
\text { process; focus } \\
\text { on active and } \\
\text { interesting } \\
\text { learning }\end{array}$ & $\begin{array}{l}\text { Teacher is a } \\
\text { guide for } \\
\text { problem } \\
\text { solving and } \\
\text { scientific } \\
\text { inquiry }\end{array}$ & $\begin{array}{c}\text { Based on } \\
\text { student's } \\
\text { interests; } \\
\text { involves the } \\
\text { application of } \\
\text { human problems } \\
\text { and affairs; } \\
\text { interdisciplinary } \\
\text { subject matter; } \\
\text { activities and } \\
\text { projects }\end{array}$ & $\begin{array}{l}\text { Relevant } \\
\text { curriculum; } \\
\text { humanistic } \\
\text { education; } \\
\text { alternative } \\
\text { and free } \\
\text { schooling } \\
\text { (Dewey, } \\
\text { Beane) }\end{array}$ \\
\hline
\end{tabular}




\begin{tabular}{|c|c|c|c|c|c|c|}
\hline $\begin{array}{l}\text { Social Recon- } \\
\text { structionism }\end{array}$ & Pragmatism & $\begin{array}{l}\text { To improve } \\
\text { and } \\
\text { reconstruct } \\
\text { society; } \\
\text { education for } \\
\text { change and } \\
\text { social reform }\end{array}$ & $\begin{array}{l}\text { Skills and } \\
\text { subjects } \\
\text { needed to } \\
\text { identify and } \\
\text { ameliorate } \\
\text { problems of } \\
\text { society; } \\
\text { learning is } \\
\text { active, } \\
\text { concerned } \\
\text { with } \\
\text { contemporary } \\
\text { and future } \\
\text { society }\end{array}$ & $\begin{array}{l}\text { Teacher } \\
\text { serves as an } \\
\text { agent of } \\
\text { change and } \\
\text { reform; acts } \\
\text { as a project } \\
\text { director and } \\
\text { research } \\
\text { leader, } \\
\text { helps } \\
\text { students } \\
\text { become } \\
\text { aware of } \\
\text { problems } \\
\text { confronting } \\
\text { humanity }\end{array}$ & $\begin{array}{l}\text { Emphasis on } \\
\text { social sciences } \\
\text { and social } \\
\text { research; } \\
\text { examining } \\
\text { social, } \\
\text { economic, and } \\
\text { political } \\
\text { problems; focus } \\
\text { on present and } \\
\text { future trends }\end{array}$ & $\begin{array}{l}\text { Equality of } \\
\text { education; } \\
\text { cultural } \\
\text { pluralism; } \\
\text { international } \\
\text { education; } \\
\text { futurism } \\
\text { (Counts, } \\
\text { Grant \& } \\
\text { Sleeter) }\end{array}$ \\
\hline $\begin{array}{l}\text { Critical } \\
\text { Theory }\end{array}$ & Marxism & $\begin{array}{l}\text { To challenge } \\
\text { and } \\
\text { deconstruct } \\
\text { society, the } \\
\text { status quo, } \\
\text { powerful } \\
\text { oppressors; to } \\
\text { teach citizens } \\
\text { to act } \\
\text { politically for } \\
\text { social justice }\end{array}$ & $\begin{array}{l}\text { Focus on how } \\
\text { the world } \\
\text { works to } \\
\text { privilege } \\
\text { some and not } \\
\text { others; } \\
\text { awareness of } \\
\text { race, class, } \\
\text { gender, } \\
\text { sexuality, and } \\
\text { (dis)ability } \\
\text { politics } \\
\end{array}$ & $\begin{array}{l}\text { Teacher } \\
\text { acts with } \\
\text { conscience } \\
\text { and resolve } \\
\text { as a social } \\
\text { agent of } \\
\text { change in } \\
\text { the world } \\
\text { with } \\
\text { students }\end{array}$ & $\begin{array}{l}\text { Teacher opens } \\
\text { up societal } \\
\text { norms to } \\
\text { criticism and } \\
\text { action }\end{array}$ & $\begin{array}{c}\text { Some forms } \\
\text { of service } \\
\text { learning } \\
\text { socially } \\
\text { active, } \\
\text { alternative } \\
\text { education } \\
\text { programs } \\
\text { (Freire, } \\
\text { Apple, } \\
\text { Giroux) }\end{array}$ \\
\hline
\end{tabular}


